\title{
Erzurum İli Hafif Raylı Sistem Güzergahının Zemin Emniyeti Açısından Yeterliliğinin Araştırılması
}

\author{
Investigation of Adequacy of Light Rail Systems Route in Erzurum Province in Terms of Ground \\ Safety
}

\author{
Ömer Lütfü AYDIN ${ }^{1} \mathbb{D}$, Emre KUŞKAPAN²* $\mathbb{D}$, Muhammed Yasin ÇODUR ${ }^{2} \mathbb{D}$ \\ ${ }^{1}$ Erzurum Büyükşehir Belediyesi, Muratpaşa Mah. Merkezi Yönetim Cad. Yakutiye, Erzurum \\ ${ }^{2}$ Erzurum Teknik Üniversitesi, Mühendislik ve Mimarlık Fakültesi, İnşaat Mühendisliği Bölümü, Erzurum
}

ÖZ

Gelişmiş ve gelişmekte olan birçok ülke toplu ulaşımda karayolu sistemlerine ek olarak raylı sistemler kullanmaktadır. Bu raylı sistemlerin en sık kullanılan türlerinden birisi ise hafif raylı sistemlerdir (HRS). HRS güzergâhları genellikle mevcut karayolu güzergâhı üzerine işlenmektedir. Bu durum zemin açısından bazı problemleri meydana getirmektedir. Raylı sistem taşıt ağırlıkları ve yolcu kapasiteleri karayolu taşıtlarına göre çok daha fazla olduğu için zemine uyguladıkları basınçlar da daha fazladır. Bununla birlikte karayolu yüzeyinde meydana gelen deformasyonlar taşıt ve yolcuları daha çok konfor yönünden etkilemekteyken raylı sistemler üzerindeki küçük deformasyonlar kaza ve ölümler gibi büyük problemleri beraberinde getirebilmektedir. $\mathrm{Bu}$ amaçla raylı sistem güzergâhının zemin yapısının incelenmesi ve uygunluk durumunun analiz edilmesi bu problemlerin önüne geçilmesi adına çok önemlidir. Yapılan bu çalışmada Erzurum il merkezinde yapılması planlanan HRS güzergâhının fiziksel zemin parametreleri açısından uygunluğu analiz edilmiştir. Analizde rotary temel sondaj, çok kanallı yüzey dalgası (MASW) ve mikrotremor yöntemleri kullanılarak elde edilen sonuçlarda bazı noktaların problemli olduğu tespit edilerek bu noktalar için zemin iyileştirmesi yapılması veya güzergâhın revize edilmesi önerilmiştir. Zemin yapısının uygun olmadığı noktalarda yolcu talebi de göz önünde bulundurularak alternatif güzergâh oluşturulmuştur.

Anahtar Kelimeler: Hafif Raylı Sistemler, Fiziksel Zemin Parametreleri, Güzergâh Uygunluk Analizi

\begin{abstract}
Many developed and developing countries use rail systems in addition to road systems in public transportation. One of the most frequently used types of these rail systems is the light rail systems (LRS). The routes of the LRS are generally preferred on the existing road route. This situation creates some problems in terms of ground conditions. Since the rail system vehicle weights and passenger capacities are much more than road vehicles, the loads they apply to the ground are also higher. However, deformations occurring on the road surface generally affect vehicles and passengers in terms of comfort, while small deformations on rail systems can bring major problems such as accidents and deaths. For this purpose, it is very important to investigate the ground structure of the rail system route and to analyze the suitability situation in order to prevent these problems. In this study, the suitability of the LRS route planned to be built in the city center of Erzurum in terms of physical properties of soil was analyzed. In the analysis, it was suggested that some locations were problematic in the results obtained by using the basic rotary
\end{abstract}


Aydın, Kuşkapan, Çodur

drilling, multichannel analysis of surface waves (MASW), and microtremor methods and ground improvement or revision of the route was suggested for these points. Where the ground condition is not suitable, an alternative route has been created by taking passenger's demand into consideration.

Keywords: Light Rail Systems, Physical Properties of Soil, Route Suitability Analysis

\section{GİRİ̧}

Dünya genelinde artan nüfusla birlikte kentleşme de giderek artmaktadır. Kent nüfusunun artması da beraberinde çeşitli ulaşım problemlerini meydana getirmektedir. $\mathrm{Bu}$ problemlerin önlenmesi amacıyla kent içi ulaşımda toplu taşıma sistemleri kullanılmaktadır. Fakat karayolu kapasitesinin yetersiz kalması ve trafik sıkışıklığının artması sebebiyle alternatif ulaşım sistemlerine ihtiyaç duyulmaktadır. $\mathrm{Bu}$ amaçla dünyanın birçok büyük kentinde HRS kullanılmaktadır.

Karayolu toplu taşıma işletmeciliği yüksek enerji sarfiyatına ve büyük miktarda zararlı gaz salınımına sebep olmaktadır. Ayrıca karayolu toplu taşıma araçlarının yolcu kapasitesi HRS'ye oranla oldukça düşüktür. HRS'nin kurulum maliyetinin ise toplu taşıma sistemlerine göre daha yüksek olması dezavantaj oluşturmaktadır (Şenlik, 2013). Fakat enerji sarfiyatının düşük olması, çevreye zararının minimum düzeyde olmas1, yolcu kapasitesinin yüksek olması ve teknolojik yapısı, gelişmiş ve gelişmekte olan ülkelerde tercih edilme durumunu artırmıştır (Candemir ve Tanyel, 2005; Baştürk, 2014; Kolos ve Taczanowski, 2016). Bu durumla birlikte HRS'nin uygulanmasından önce geniş fizibilite çalışmalarının yapılması gereklidir. Raylı sistemin geçeceği güzergâhın belirlenmesi, başlangıç bitiş noktalarının tespiti, karayolu ile kesişim noktalarının düzenlenmesi ve aktarma merkezlerinin belirlenmesi gibi birtakım ön aşamalar gerçekleştirilmektedir (Ocak ve Manisalı, 2006). Belirlenen aşamaların aksatılması veya eksik yapılması durumunda
HRS için belirlenen talebin çok daha altına düşülebilmektedir (Kaya, 2005; Murteza, 2010; Erdoğan, 2011; Harami ve Furlan, 2020).

Yapılmakta olan fizibilite çalışmalarından bir diğeri ise HRS'nin geçeceği güzergâhtaki zemin durumunun incelenmesidir. Fakat bu aşamanın göz ard1 edilmesi veya yeteri kadar önem verilmemesi büyük problemleri beraberinde getirmektedir (Argyroudis ve Kaynia, 2013). $\mathrm{Bu}$ aşamanın göz ardı edilmesindeki en önemli hususlardan birisi HRS'nin mevcut karayolu güzergâh1 üzerine işlenmesidir. Mevcut karayolu taşıtlarının geçtiği zeminde oluşan küçük deformasyonların HRS güzergâhında oluşması ise çok büyük problemlere sebep olabilmektedir (Tarhan ve Akpınar, 2005; Cui vd., 2019). Ayrıca HRS taşıtlarının yüksek tonajlı ve yolcu kapasitesinin çok olması zemine uyguladığı basıncı artırmaktadır. Bu basınç da zemindeki deformasyonları artırabilmektedir. Karayollarında araç trafiğinin getirdiği basınç ve doğal afetlerden (yağışlar, heyelanlar, depremler vs.) dolayı çeşitli deformasyonlar meydana gelmekte fakat bu durum trafik akışını çoğunlukla konfor yönünden etkilemektedir. Karayollarında bulunan HRS hatlar1 ise bu deformasyonlardan çok tehlikeli boyutlarda etkilenebilmektedir. HRS raylar üzerinde ilerlediği için bu raylarda meydana gelecek çökme, dönme ve ayrılma gibi durumlar taşıtlarda devrilme, raydan çıkma ve çarpışma gibi çok büyük kazalara neden olabilmektedir (Gündüz vd., 2011). Bahsedilen kaza ve problemlerin önüne geçilebilmesi için zemin yapısının detaylı incelenmesinin yanı sıra meydana gelebilecek senaryolara da hazırlıklı 
olmak gereklidir (Önder ve Akdemir, 2019). Zeminlerde oluşabilecek deformasyonları incelemek için raylı sistemlerin geçtiği güzergâh için çeşitli altyapı analiz yöntemleri yürütülmektedir. Analiz yapılabilmesi için ise zemin yapısı, sınıfı ve özellikleri hakkında bilgiler içeren zemin etütlerinden yararlanılmaktadır. Bu etütler ve testler sayesinde zemin performans parametreleri belirlenebilmektedir. Belirlenen parametrelere çeşitli analiz yöntemleri uygulanarak zemin yapısının hangi şartlarda uygun olup hangi şartlarda uygun olmadiğ1 hakkında yorumlar yapılabilmektedir (Stenström, 2014; Bergquist ve Söderholm, 2014).

Yapılan bu çalışmada Erzurum ili için belirlenen HRS güzergâhının fiziksel zemin parametreleri açısından uygunluğu analiz edilmiştir. Erzurum ilinde mikrobölgeleme yöntemi ile oluşturulan zemin etüt çalışmalarının fiziksel parametrelere göre sinıflandirılması yapılmıştır. HRS güzergâhı rotary temel sondaj, MASW, mikrotremor yöntemleriyle incelenerek zemin yapısı değerlendirilmiştir. Elde edilen sonuçlarda HRS güzergâhının bazı noktalarının problemli olduğu tespit edilerek bu noktalar için zemin iyileştirmesi yapılması veya güzergâhın revize edilmesi önerilmiştir. Zemin yapısının uygun olmadığı noktalarda yolcu talebi de göz önünde bulundurularak değişikliğe gidilmiş ve alternatif güzergâh oluşturulmuştur.

\section{MATERYAL VE YÖNTEM}

\section{Çalışma Alanı}

Çalışma alanı olarak belirlenen Erzurum ili için ilk jeoloji çalışmaları, Mercier (1948), Erentöz (1949) ve Altınlı (1963) tarafindan yapılmıştır. Bu çalışmalar sonucu, yörenin önemli kaya türleri ve stratigrafisi genel çizgileriyle belirlenmiştir. Erdoğan ve Soytürk (1974)'e ait çalışma, yukarıda belirtilen 1/25.000 ölçekli çalışmaların bir bileşimi durumundadır. Mevcut bulgular ile arazi gözden geçirilerek bu bölge ile ilgili çeşitli çalışmalar yapılmıştır (Yılmaz vd., 1988; Y1ldırım ve Parlak 2008; Şafak ve Kaya 2016; Y1lmaz ve Y1lmaz, 2016).

İnceleme alanı, Erzurum ili merkezini kapsamaktadır (Şekil 1). Bu çalışmada alanda 2014 yılında hazırlanan Erzurum ili nazım imar planı jeolojik-jeoteknik etüt verileri yardımıyla HRS güzergâhı analiz edilerek uygulama projeleri yapılırken jeoteknik proje hazırlanması gereken alanların tespit edilmesi amaçlanmıştır.

\section{Hafif Raylı Sistem Özellikleri}

Türkiye'de raylı sistem 1856 y1lından beri kullanılmakta olup, yerli üretim HRS 2012 y1lı itibariyle kullanılmaya başlanmıştır. Günümüzde yerli olarak üretilen ve kullanılmakta olan 3 farklı firmaya ait tramvay türü vardır (Bozankaya, 2020; Durmazlar, 2020; Burulaş, 2020). Bu tramvaylar yolcu kapasite türlerine göre birtakım farklılıklar içermektedir. $\mathrm{Bu}$ özellikler genel olarak uzunluk, genişlik, ağırlık, azami hız, azami ivmelenme ve azami aks yükü türünde belirlenmiştir. Yolcu taşıma kapasitesi bakımından kalabalık yolcu kitlesi taşıyan ve hizlı hareket eden bu HRS ve metro hatlarında S49 ray1 diye tanımlanan mantar tipi raylar kullanılmaktadır (Tarhan, 2009). Bu ray yapısının ölçüleri Şekil 2'de gösterilmektedir. Bu ray tipi dikkate alınarak, yerli hafif raylı sistemler olarak Durmazlar/İpekböceği, Durmaray ve Bozankaya firmalarının üretmiş olduğu araçların özellikleri ve taşıtlarının zemine uyguladıkları ortalama basınçlar Çizelge 1'de gösterilmektedir. 
Aydın, Kuşkapan, Çodur

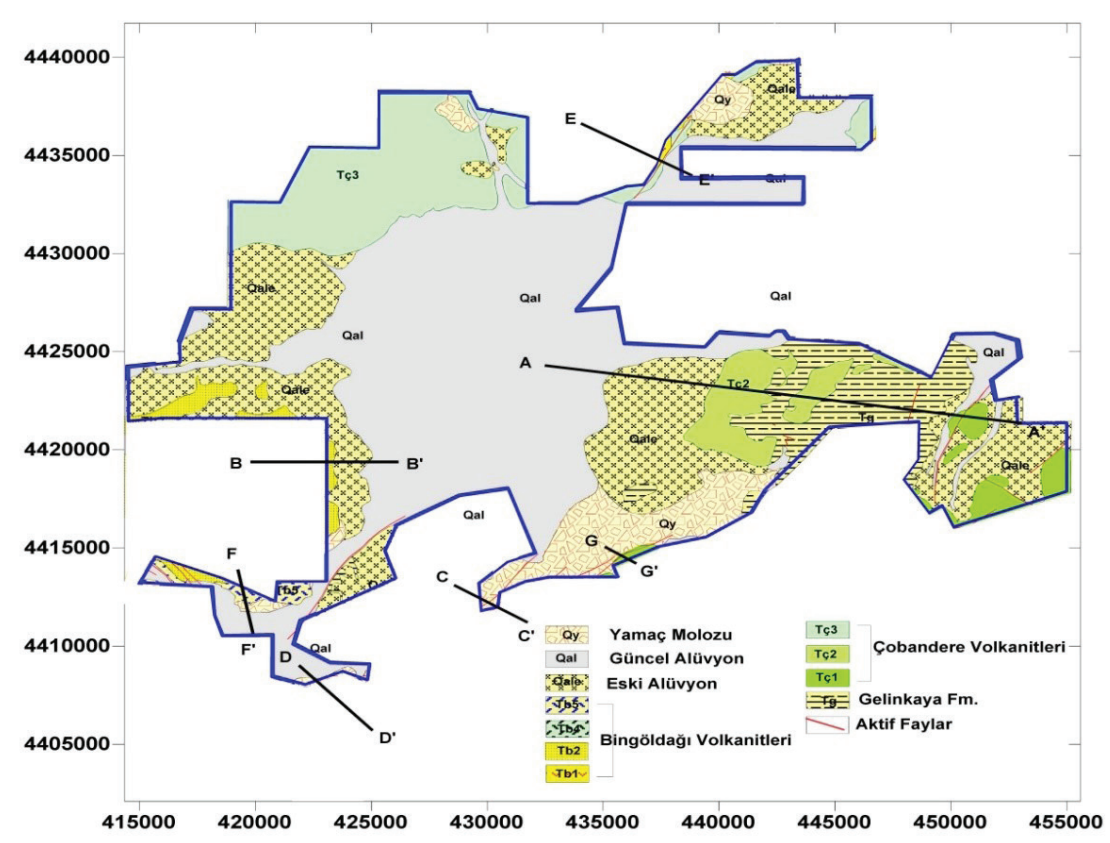

Şekil 1. İnceleme alanını kapsayan Erzurum ve çevresinin jeoloji haritası (Erzurum Büyükşehir Belediyesi, 2014). Figure 1. Geological map of Erzurum and its surrounding including the study area (Erzurum Metropolitan Municipality, 2014).

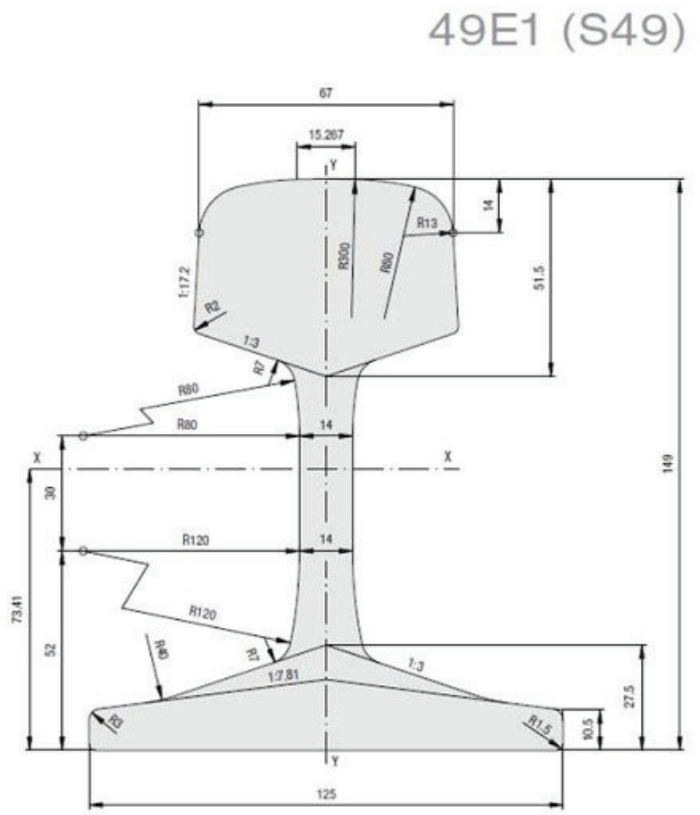

Şekil 2. S49 tipi çelik ray profil ölçüleri (Railwayrail, 2015).

Figure 2. Profile dimension of S49 steel rail (Railwayrail, 2015). 
Çizelge 1. Türkiye'de üretilen ve kullanılmakta olan bazı tramvay çeşitleri ve özellikleri.

Table 1. Tram types and properties that are used and produced in Turkey.

\begin{tabular}{l|c|c|c}
\hline Teknik Özellikler & Bozankaya Tramvay & Durmaray & Durmazlar/ İpekböceği \\
\hline Uzunluk & $32.7 \mathrm{~m}$ & $29 \mathrm{~m}$ & $27.8 \mathrm{~m}$ \\
Genişlik & $2.65 \mathrm{~m}$ & $2.45 \mathrm{~m}$ & $2.4 \mathrm{~m}$ \\
Ağırlık & $41.9 \mathrm{ton}$ & $38.5 \mathrm{ton}$ & $34 \mathrm{ton}$ \\
Toplam Yolcu Kapasitesi & $295 \mathrm{kişi}$ & $274 \mathrm{kişi}$ & $250 \mathrm{kişi}$ \\
Azami Hız & $70 \mathrm{~km} / \mathrm{sa}$ & $70 \mathrm{~km} / \mathrm{sa}$ & $50 \mathrm{~km} / \mathrm{sa}$ \\
Azami İvmelenme & $1.3 \mathrm{~m} / \mathrm{s}^{2}$ & $1.3 \mathrm{~m} / \mathrm{s}^{2}$ & Bilinmiyor \\
Ortalama Basınç (Dolu iken) & $0.71 \mathrm{~kg} / \mathrm{cm}^{2}$ & $0.77 \mathrm{~kg} / \mathrm{cm}^{2}$ & $0.69 \mathrm{~kg} / \mathrm{cm}^{2}$ \\
Ortalama Basınç (Boşken) & $0.51 \mathrm{~kg} / \mathrm{cm}^{2}$ & $0.53 \mathrm{~kg} / \mathrm{cm}^{2}$ & $0.48 \mathrm{~kg} / \mathrm{cm}^{2}$ \\
\hline
\end{tabular}

Trenlerin zemin taşıma gücüyle bağlantılı en önemli kriterleri tren ağırlığ ve yolcu kapasitesidir. Her iki kriterin artması zemine uygulanan basınc1 artırmaktadır. Ayrıca HRS sistem için belirlenen taşıtın ortalama ağırlığı ve yolcu kapasitesi bir karayolu taşıtından oldukça yüksek değere sahiptir. $\mathrm{Bu}$ durumla birlikte raylı sistem taşıtlarının raylara temas yüzeyi olan tekerlerin boyutları karayolu taşıtlarına göre daha küçüktür. Tren tekerleri ise basıncı raylar aracılığı ile zemine iletmektedir. $\mathrm{Bu}$ sebeple karayolu taşıtlarına göre farkl1lık göstermektedir. Karayolu yüzeyinde meydana gelen deformasyonlar genel olarak karayolu taşıtlarının konfor açısından etkilenmesine sebep olmaktadır. Öte yandan raylı sistem üzerinde meydana gelen deformasyonlar ise raylar arasındaki bağlantının bozulmasına sebep olduğu için ciddi kazalara sebebiyet vermektedir. $\mathrm{Bu}$ amaçla akı1lı ulaşım sistemleri ve teknolojinin gelişmesi ile raylar üzerindeki deformasyonları incelemek amaciyla raylı sistem taşıtları da geliştirilmiştir. Fakat bu taşıtlar raylar üzerinde sürekli gidip gelmediği için anlık değişimleri fark edememektedir. Bu kapsamda raylı sistemler üzerindeki deformasyonu minimize etmek ve bundan kaynaklı kazaları önleyebilmek amacıyla HRS sistem uygulanmadan önce uygulama güzergâhının zemin yapısının uygunluk analizi yapılmalıdır. $\mathrm{Bu}$ analiz sayesinde zemin yapısında problem oluşturacak bölgeler tespit edilerek güzergâhın değiştirilmesi bahsedilen problemlerin önüne geçilmesi adına çok önemlidir.

Erzurum ilinde yapılmas1 planlanan hafif raylı sistemin güzergâhı Şekil 3'te gösterilmektedir. Buna göre yapılması planlanan raylı sistem hattı yaklaşı 15 kilometre uzunluğunda olup, toplam 16 duraktan oluşmaktadır. Duraklar arası mesafe çeşitlilik göstermekle birlikte ortalama 1 kilometredir. Ayrıca her bir durak için 100 metrelik bir mesafe ayrılmıştır. Tek yönlü olarak tasarlanmış olan bu hat, İstasyon Meydanı'ndan harekete başlayıp Erzurum Kalesi, Şehir Merkezi, Atatürk Üniversitesi, Yıldızkent, Yenişehir, Yunusemre Mahallesi bölgelerinden geçerek yine İstasyon Meydanı'nda hareketini sonlandırmaktadır (Erzurum Büyükşehir Belediyesi, 2018). 


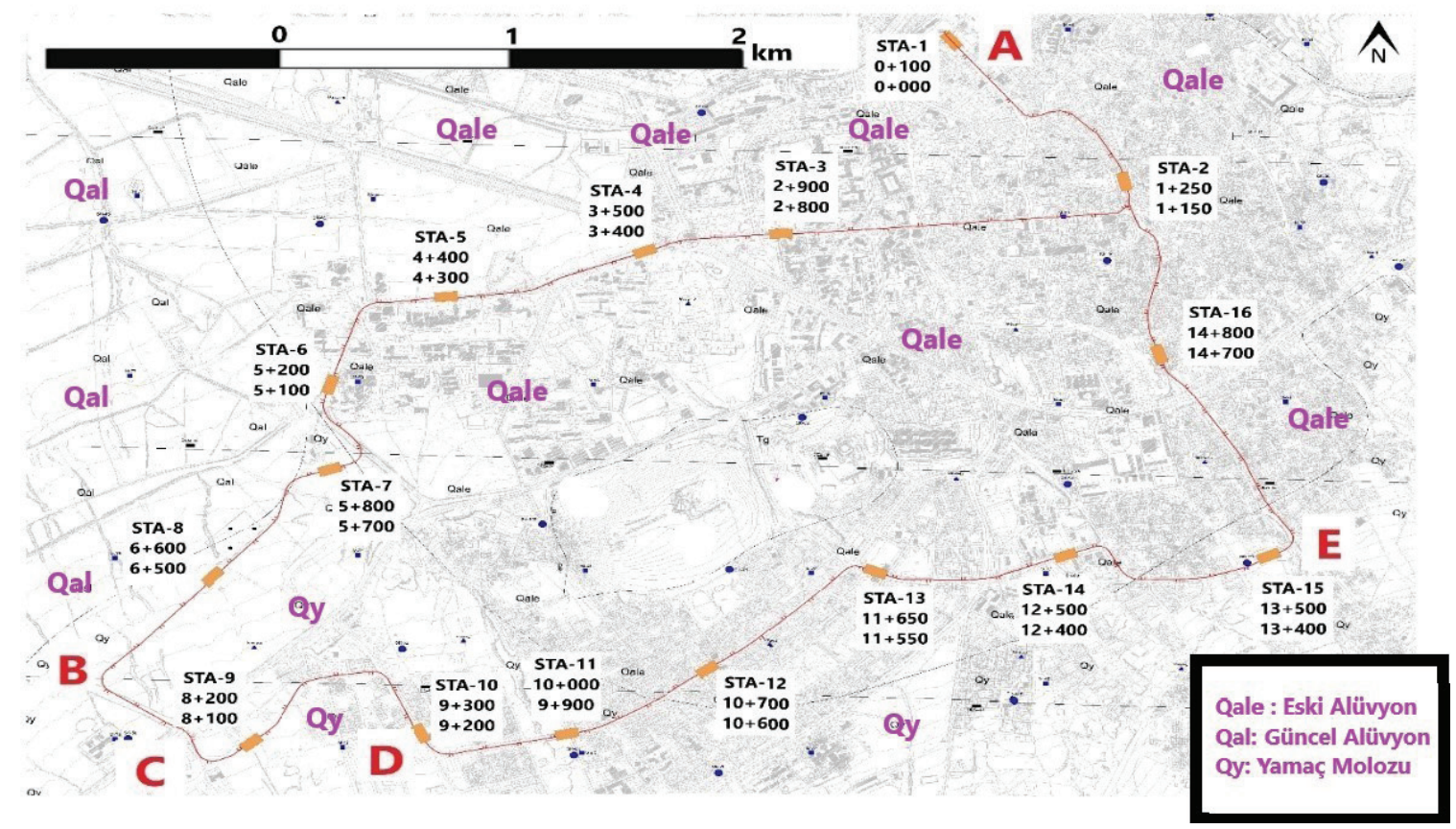

Şekil 3. Erzurum ili jeoloji haritası üzerine işlenmiş HRS güzergâh1.

Figure 3. The LRS route on the geological map of Erzurum province.

Şekil 1 ve 3'te verilen jeolojik bilgiler dahilinde; HRS hattının geçtiği bölgelerin zemin özellikleri farklılık gösterdiği görülmektedir. Fakat çalışma alanının önemli bir kısmında alüvyon ve bazı kısımlarda ise yamaç molozu yapısı yer almaktadır. Aynı zamanda Erzurum ilinin Palandöken Dağı eteğine kurulu olmas1 itibariyle topoğrafik eğim değişkenlik göstermektedir. $\mathrm{Bu}$ durumlara ilaveten iklim yapısı itibariyle kış aylarında meydana gelen karların ilkbahar aylarında erimesi ve yaz aylarının yağışlı geçmesi sebebiyle yeraltı su seviyesi oldukça yüksektir. Bu kapsamda yapılan arazi çalışmaları ve bu çalışmalardan elde edilen zemin etüt sonuçlarının değerlendirilmesi gerekmektedir.

\section{ARAZİ ÇALIŞMALARI}

İnceleme alanının jeolojik verileri doğrultusunda, birimlerin yanal ve düşey yöndeki değişimlerini, mühendislik özelliklerini ve fiziksel ve mekanik parametrelerini saptamak amaciyla, derinlikleri $10 \mathrm{~m}$ ile $20 \mathrm{~m}$ arasında değişen 181 adet olmak üzere toplam $2536 \mathrm{~m}$ uzunluğunda temel sondaj1, dinamik elastisite parametrelerini saptamak, zemin büyütmesi ve zemin hakim periyodunu belirlemek amaciyla, 150 adet mikrotremor, 62 adet MASW, 12 adet sismik kırılma ve 75 adet düşey elektrik sondaj1 (DES) çalışması gerçekleştirilmiştir.

Yapılan çalışmalar 1şı̆̆ında HRS güzergâhına isabet eden 8 adet sondaj, 13 adet Mikrotremor, 5 adet MASW etüt sonuçları ile değerlendirme yapılmıştır. Yerinde yapılan deneysel çalışmaların lokasyonları Şekil 4'te gösterilmektedir. 


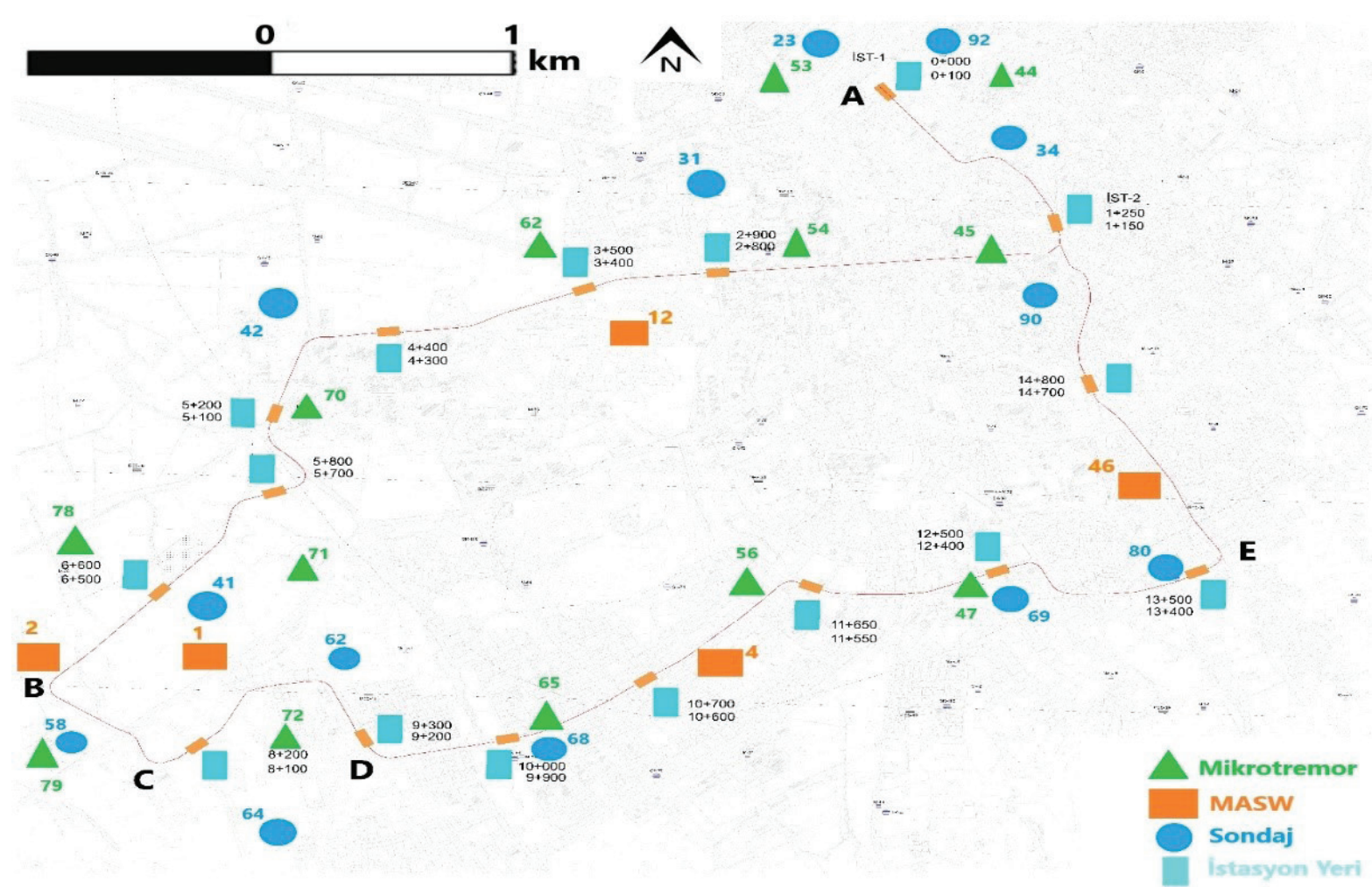

Şekil 4. HRS güzergâhına yakın bölgelerde bulunan Mikrotremor, MASW ve sondaj lokasyonları.

Figure 4. Locations of microtremor, borehole and MASW located in areas close to the LRS route.

\section{Çok Kanallı Yüzey Dalgası Analiz Yöntemi (MASW)}

MASW yöntemleri ile yeraltındaki formasyonların derinlikleri, tabakaların kalınlıkları, eğimi, kırık, fay, süreksizlik zonları, tabaka hızları ve elde edilen bu bilgilerden yeraltı yapısının dinamik ve elastik parametrelerini bulmak mümkündür (Kır, 2007). Yap1 ve zemin incelemelerinde $\mathrm{S}$ dalgası hızını elde edebilen çeşitli uygulamalarla da modelleyebilen bir yöntem olan MASW yöntemi diğer sismik prospeksiyon yöntemlerinden daha derinden veri alabiliyor olması sinyal/gürültü oranının yetersiz kaldığı şehir içi çalışmalarda ihtiyaç duyulan 30 metre ve üstü derinliklerden veri alınmasına olanak sağlamaktadır. Bu sebeple şehir içi zeminin fiziksel parametrelerinin belirlenmesi gereken çalışmalarda sıklıkla kullanılmaktadır. MASW yöntemi ile elde edilebilen verilere ek olarak zemin hakim periyodu da yüksek doğrulukla hesaplanabilmekte ve mikrotemor ölçümleriyle hesaplanan zemin hakim titreşim periyodu ile karşılaştırılabilmektedir. Ayrıca, doğal zemine gerek duyulmaksızın asfalt, beton, kaldırım, taş zemin vb. ortamlarda da jeofonların satıhla iyi bir bağlantısı sağlanarak ölçüm alınabilmektedir. MASW yöntemi, maliyeti düşük olması ve çevreyle olan uyumu sayesinde tercih edilebilecek yöntemlerden birisidir. Aktif kaynak uygulamalarında doğrusal hat boyunca dizili jeofonlara belirli uzaklıktan balyozla vurulması sonucunda sismik dalgalar kaydedilir (Şekil 5). 
Aydın, Kuşkapan, Çodur

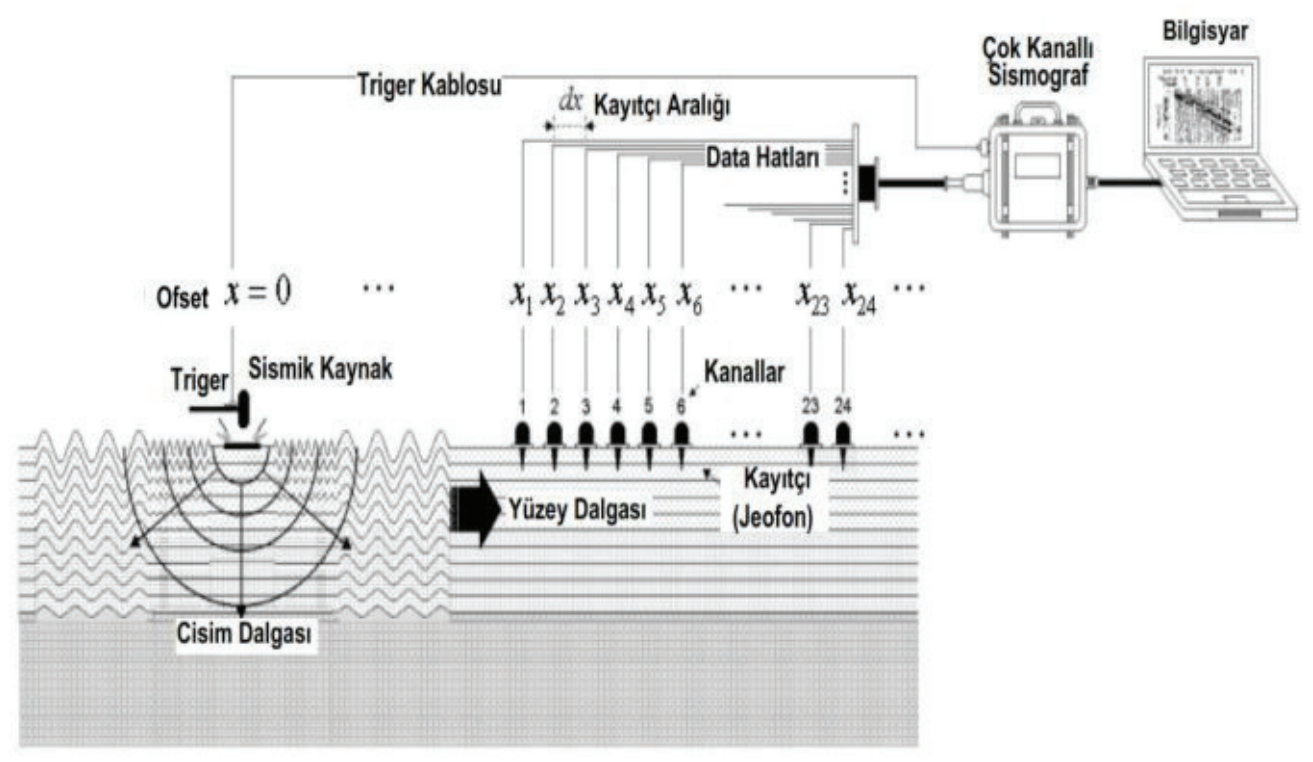

Şekil 5. MASW yönteminde temel işlem adımları (Dikmen vd., 2009).

Figure 5. Basic steps in MASW method (Dikmen et al., 2009).

Yapay sismik kaynak ile yüzey dalgası kayıtları arazi etütleriyle toplandıktan sonra çeşitli veri işlem aşamalarına geçilir. İlk aşamada değişik frekanslara karşılık gelen faz hızları program vasıtası ile çizdirilir. İşlem sonucunda dispersiyon eğrisi elde edilir. Elde edilen dispersiyon eğrisinin yine program vasıtası ile frekans aralıkları belirlenir. Farklı modellerde ters çözüm uygulanarak derinliğe bağlı S dalgası hızları hesaplanır. Buna göre, çalışma güzergâhında bulunan MASW ölçümleri ve bu ölçümler neticesinde elde edilen $\mathrm{V}_{\mathrm{s} 1}, \mathrm{~V}_{\mathrm{s} 30}$, birinci tabaka kalınlığı ve tabaka sayısı değerleri Çizelge 2 ve Çizelge 3 'te gösterilmektedir. HRS taşıtları metro gibi raylı sistem taşıtlarının aksine zemin yüzeyinde hareket ettikleri için temel etki alanları ve temel derinlikleri zemin yüzeyine yakın olmaktadır. Bu sebeple zemin özellikleri incelenirken MASW değerleri için zemine yakın tabaka kalınlıkları dikkate alınmaktadır.
Çizelge 2. $\mathrm{V}_{\mathrm{s} 1}$ hızı, birinci tabaka kalınlığı (h1) ve değerlendirme sonucu elde edilen tabaka sayısı.

Table 2. $V_{\text {sl }}$ velocity, first layer thickness ( $\left.h 1\right)$, and the number of layers obtained by evaluation.

\begin{tabular}{c|cc|cc}
\hline \multirow{2}{*}{ Ölçüm No } & \multicolumn{2}{|c|}{$\mathrm{V}_{\mathrm{sl}}(\mathrm{m} / \mathrm{s})$} & \multirow{2}{*}{ h1(m) } & Tabaka \\
\cline { 2 - 3 } & 1. Tabaka & 2. Tabaka & & Sayıs1 \\
\hline MASW-1 & 290 & 335 & 6.3 & 10 \\
MASW-2 & 290 & 321 & 7.0 & 15 \\
MASW-4 & 237 & 313 & 6.0 & 6 \\
MASW-12 & 275 & 329 & 6.3 & 9 \\
MASW-46 & 311 & 313 & 3.8 & 10 \\
\hline
\end{tabular}

Çizelge 3. Çalışma alanında hesaplanan $\mathrm{V}_{\mathrm{s} 30}$ değerleri. Table 3. Calculated $V_{s 30}$ values in the study area.

\begin{tabular}{c|c}
\hline Ölçüm No & $\mathrm{V}_{\mathrm{s} 30}(\mathrm{~m} / \mathrm{s})$ \\
\hline MASW-1 & 414 \\
MASW-2 & 404 \\
MASW-4 & 494 \\
MASW-12 & 423 \\
MASW-46 & 419 \\
\hline
\end{tabular}




\section{Temel Sondajları}

Sondaj özel bir takım gereçlerle her türlü katı ortamda, her yönde, işletme veya özel amaçlı silindirik delikler açma işlemi ve silindirik şekilde derin kazı makinaları ile kazı işlemidir. Araştırma alanında sulu sistem rotary sondajlar yapılarak, her 1.5 metrede bir SPT deneyi gerçekleştirilmiş ve 3 metrede bir örselenmemiş örnek (UD) alınmıştır. Yapılan sondajların derinliklere göre geçtiği zemin türleri belirlenmiştir (Çizelge 4).
Sondajlarda her 1.5 metrede bir yapılan SPT ve 3 adet UD örnekleri zemin mekaniği laboratuvarında değerlendirilmiştir. Değerlendirme sonuçları Çizelge 5'te verilmiştir.

Çalışma alanı sınırlarına isabet eden sondajlardan iki tanesi (SK-68 ve SK-73) kaya birim içerisinde yeteri kadar ilerleyebilmiş ve boyu $50 \mathrm{~cm}$ 'nin üzerinde olan numunelerde nokta yükleme deneyi yapılmıştır (Çizelge 6). Alanda bulunan diğer sondaj noktalarında kaya birimde ilerleme yapılamadığı için dayanım deneyi yapılabilecek numune alınamamıştır.

Çizelge 4. İnceleme alanında açılan sondajlarda geçilen zemin türlerinin derinliğe göre değişimi.

Table 4. Variation of the soil units in the boreholes of the study area according to depth.

\begin{tabular}{ccl}
\hline Sondaj No & Derinlik $(\mathrm{m})$ & \\
\hline SK-23 & $0.0-15.00$ & Kahve renkli çakıllı siltli kumlu kil \\
\hline SK-31 & $0.0-30.50$ & Koyu kahve renkli çakıllı kum \\
\hline SK-41 & $0.0-20.00$ & Koyu kahve kil \\
\hline SK-42 & $0.0-30.00$ & Koyu kahve renkli irili ufaklı çakıllı siltli kumlu kil \\
\hline SK-58 & $0.0-16.58$ & Kahve renkli çakıllı kum \\
\hline SK-62 & $0.00-15.3$ & Az siltli, kahve renkli çakıllı kum \\
\hline SK-64 & $0.0-15.22$ & Kahve renkli siltli çakıllı kum \\
\hline SK-68 & $0.00-2.00$ & İnce kumlu çakıllı blok \\
& $2.00-16.5$ & Kahve renkli bazalt \\
\hline SK-69 & $0.00-16.5$ & Az siltli, çak1llı kum \\
\hline SK-80 & $0.00-2.00$ & Kahve renkli kumlu çakıllı silt \\
& $2.00-4.00$ & Az çakıllı, siltli kum \\
& $4.00-15.0$ & Kahve renkli çakıllı killi kum \\
\hline SK-90 & $0.00-3.50$ & Siltli kil \\
& $3.50-15.0$ & Siyahımsı kahve killi kum \\
\hline SK-92 & $0.00-6.00$ & Siltli kum \\
& $6.0-13.51$ & Az siltli, kumlu çakıl \\
\hline
\end{tabular}


Aydın, Kuşkapan, Çodur

Çizelge 5. İnceleme alanında yer alan zeminlerin fiziksel parametreleri.

Table 5. Physical parameters of the soils in the study area.

\begin{tabular}{|c|c|c|c|c|c|c|c|c|c|}
\hline \multirow{2}{*}{$\begin{array}{l}\text { Sondaj } \\
\text { No }\end{array}$} & \multirow{2}{*}{$\begin{array}{c}\text { Numune } \\
\text { No }\end{array}$} & \multirow{2}{*}{$\begin{array}{l}\text { Derinlik } \\
(\mathrm{m})\end{array}$} & \multirow{2}{*}{$\begin{array}{c}\mathrm{Su} \\
\text { İçeriği } \\
(\%)\end{array}$} & \multicolumn{2}{|c|}{ Elek Analizi } & \multicolumn{3}{|c|}{ Atterberg Limitleri } & \multirow{2}{*}{$\begin{array}{c}\text { Zemin } \\
\text { Sinıfi }\end{array}$} \\
\hline & & & & $\begin{array}{c}\text { No. } 4 \\
\text { Kalan } \\
(\%)\end{array}$ & $\begin{array}{c}200 \\
\text { Geçen } \\
(\%)\end{array}$ & $\begin{array}{l}\text { LL } \\
(\%)\end{array}$ & $\begin{array}{l}\text { PL } \\
(\%)\end{array}$ & $\begin{array}{l}\text { PI } \\
(\%)\end{array}$ & \\
\hline \multirow[t]{2}{*}{ SK-23 } & SPT-3 & $3.00-3.45$ & 28.37 & 47.54 & 30.05 & 36.9 & 20 & 16.9 & $\mathrm{GC}$ \\
\hline & SPT-6 & $6.00-6.45$ & 6.56 & 50.4 & 26.88 & 34.2 & 21.5 & 12.7 & \\
\hline \multirow[t]{2}{*}{ SK-31 } & SPT-1 & $1.50-1.95$ & 16.26 & 17.99 & 50.52 & 41.10 & 21.1 & 20.0 & $\mathrm{CL}$ \\
\hline & SPT-9 & $24.0-24.5$ & 14.74 & 25.00 & 44.81 & 37.90 & 20.6 & 17.3 & $\mathrm{SC}$ \\
\hline \multirow{2}{*}{ SK-34 } & SPT-2 & $3.00-3.45$ & 38.83 & 29.83 & 29.28 & 37.6 & 20.3 & 17.3 & $\mathrm{SC}$ \\
\hline & SPT-4 & $6.00-6.45$ & 13.50 & 15.86 & 67.59 & 46.6 & 22.8 & 23.8 & $\mathrm{CL}$ \\
\hline \multirow{2}{*}{ SK-41 } & SPT-1 & $1.50-1.75$ & 6.99 & 32.52 & 43.47 & \multirow{2}{*}{38.6} & \multirow{2}{*}{20.2} & \multirow{2}{*}{18.4} & GC \\
\hline & SPT-3 & $9.00-9.50$ & 10.24 & 40.99 & 24.10 & & & & GM \\
\hline \multirow{2}{*}{ SK-42 } & SPT-2 & $4.50-4.75$ & 7.10 & 46.45 & 41.26 & \multirow{2}{*}{37.6} & \multirow{2}{*}{23.1} & \multirow{2}{*}{17.5} & $\mathrm{GC}$ \\
\hline & SPT-5 & $12.0-12.45$ & 7.06 & 45.59 & 21.18 & & & & GM \\
\hline \multirow{2}{*}{ SK-58 } & SPT-6 & $9.00-9.45$ & 20.8 & 6.10 & 11.8 & & $\mathrm{NP}$ & & SM-SW \\
\hline & SPT-8 & $12.0-12.45$ & 12.2 & 31.3 & 5.3 & & $\mathrm{NP}$ & & SW-SM \\
\hline \multirow{3}{*}{ SK-62 } & SPT-1 & $1.50-1.95$ & 11.5 & 41.1 & 18.2 & & $\mathrm{NP}$ & & GM \\
\hline & SPT-2 & $3.00-3.45$ & 6.6 & 33.5 & 15.9 & 28.6 & 18.3 & 10.3 & $\mathrm{SC}$ \\
\hline & SPT-10 & $15-15.45$ & 13.4 & 0.0 & 12.4 & & $\mathrm{NP}$ & & SM \\
\hline \multirow{2}{*}{ SK-64 } & SPT-4 & $6.00-6.45$ & 7.9 & 4.0 & 56.4 & 30.5 & 15.4 & 15.1 & $\mathrm{CL}$ \\
\hline & SPT-10 & $15-15.45$ & 13.5 & 34.9 & 15.0 & & $\mathrm{NP}$ & & SM \\
\hline \multirow{3}{*}{ SK-80 } & SPT-2 & $3.00-3.45$ & 7.9 & 33.2 & 18.0 & & $\mathrm{NP}$ & & SM \\
\hline & SPT-4 & $6.00-6.45$ & 4.1 & 21.4 & 20.6 & 29.5 & 18.4 & 11.1 & $\mathrm{SC}$ \\
\hline & SPT-6 & $9.00-9.45$ & 5.4 & 26.6 & 23.3 & & $\mathrm{NP}$ & & SM \\
\hline \multirow{2}{*}{ SK-90 } & SPT-2 & $3.00-3.45$ & 19.8 & 1.9 & 63.8 & 29.3 & 18.2 & 11.1 & $\mathrm{CL}$ \\
\hline & SPT-10 & $15-15.45$ & 7.8 & 31.8 & 27.0 & 27.3 & 16.5 & 10.8 & $\mathrm{SC}$ \\
\hline SK-92 & SPT-2 & $3.00-3.45$ & 26.2 & 27.6 & 19.9 & & $\mathrm{NP}$ & & SM \\
\hline
\end{tabular}


Çizelge 6. İnceleme alanındaki kaya birimlerin mekanik parametreleri.

Table 6. Mechanical parameters of the rock units in the study area.

\begin{tabular}{cccccc}
\hline Sondaj No & Numune No & $\begin{array}{c}\text { Derinlik } \\
(\mathrm{m})\end{array}$ & $\begin{array}{c}\text { Doğal Birim } \\
\text { Hacim Ağılık } \\
\left(\mathrm{kN} / \mathrm{m}^{3}\right)\end{array}$ & $\begin{array}{c}\text { Yenilme Yükü } \\
\mathrm{P}(\mathrm{kg})\end{array}$ & $\begin{array}{c}\text { Nokta Yükleme } \\
\text { Değeri } \\
\mathrm{I}_{\mathrm{s}}\left(\mathrm{kgf} / \mathrm{cm}^{2}\right)\end{array}$ \\
\hline SK-68 & KAROT-1 & $4.50-4.95$ & 24.16 & 605 & 20.7 \\
SK-68 & KAROT-2 & $15-15.45$ & 25.50 & 1162 & 39.8 \\
SK-73 & KAROT-1 & $4.50-4.95$ & 24.19 & 711 & 24.4 \\
\hline
\end{tabular}

\section{Yeraltı Su Seviyesi}

Erzurum Ovası'nı çevreleyen dağ ve tepelerden ovaya doğru yeraltı ve yerüstü suyu ile sürekli beslenme olması ve havza içerisinden de Karasu Çayı'nın geçmesi nedeniyle ovaya sürekli su girişimi olmaktadır. $\mathrm{Bu}$ nedenle ovadaki yeraltı suyu seviyesi (YASS) yüzeye yakın seviyelerde yer almaktadır. İnceleme alanında Erzurum Ovası'nda açılan kuyuların genelinde yeraltı suyu yüzeye yakın seviyelerde gözlenmektedir. Dağ etekleri ve yamaçlarında ise daha derinlerde yeraltı suyu seviyesine rastlanmıştır. İnceleme alanının yeraltı su seviyesi dağılım haritası yapılarak, su akış yönünü ve suyun toplanma yerleri konusunda bilgi elde edilmeye çalışılmıştır. Erzurum il merkezinde yeraltı su seviyesi $0.50 \mathrm{~m}$ ile 13.00 $\mathrm{m}$ arasında değişmektedir (Çizelge 7). Yeraltı suyu seviyesi haritasında görüldüğü üzere, yeraltı suyu derinliğinin havza ortasında $0.5 \mathrm{~m}$ ile $3.0 \mathrm{~m}$; havza kenarlarına doğru $3.0 \mathrm{~m}$ ile 13.0 $\mathrm{m}$ aralığında değiştiği görülmektedir (Şekil 6).

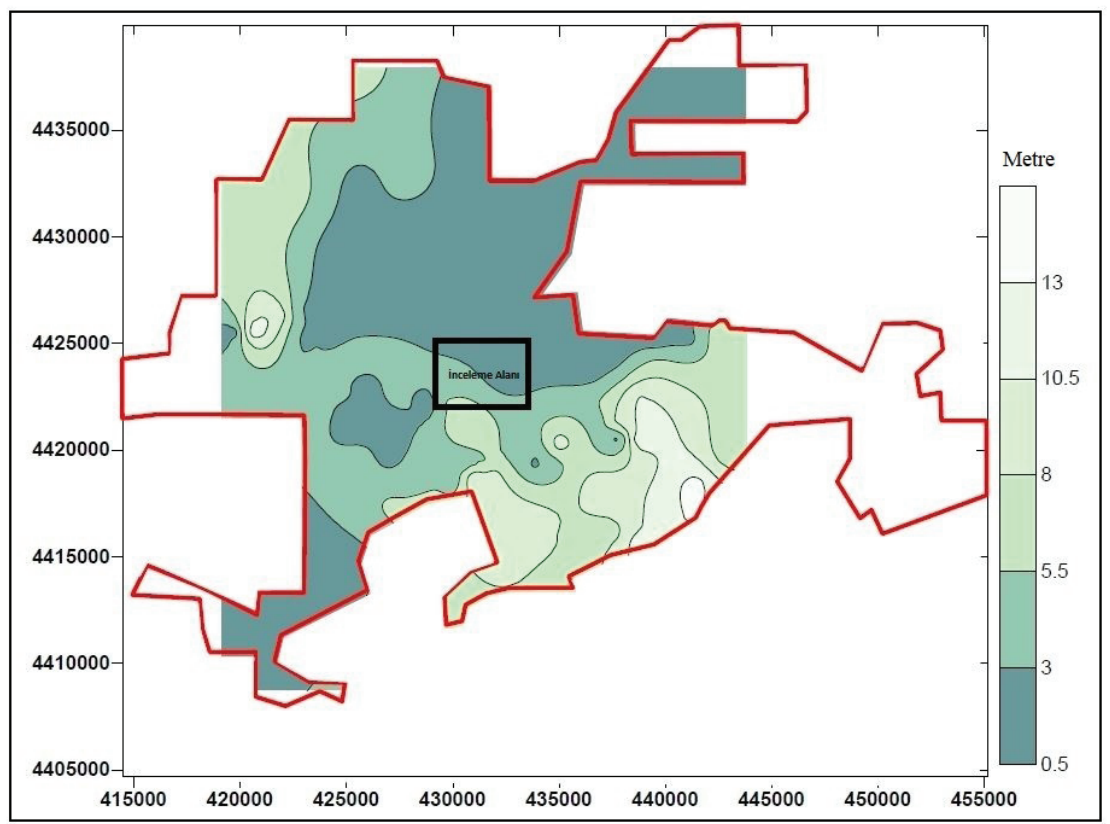

Şekil 6. Erzurum il merkezi yeraltı suyu seviyesi haritası.

Figure 6. Groundwater level map of Erzurum city center. 
Aydın, Kuşkapan, Çodur

Çizelge 7. İnceleme alanındaki sondaj kuyularında yeralt1 su seviyesi.

Table 7. Groundwater level in the boreholes at the study area.

\begin{tabular}{c|c}
\hline Kuyu No & YASS $(\mathrm{m})$ \\
\hline SK-23 & 2.00 \\
SK-31 & - \\
SK-34 & - \\
SK-41 & 9.00 \\
SK-42 & - \\
SK-58 & 9.80 \\
SK-62 & - \\
SK-64 & 8.00 \\
SK-68 & - \\
SK-69 & - \\
SK-80 & - \\
SK-90 & - \\
SK-92 & 2.10 \\
\hline
\end{tabular}

\section{Zemin Taşıma Gücü}

Taşıma gücü, temel altında bulunan zeminin herhangi bir yük altındaki etkileşim, yani kaymaya ve göçmeye karşı göstereceği zemin direncini ifade eder. Bir zeminin taşıma gücü etki derinliği; üzerine gelecek olan yapı temel genişliğinin yaklaşık iki katı olarak kabul edilir (Şekercioğlu, 1993). İnceleme alanındaki eski ve güncel alüvyon birimler ile yamaç molozu ve alüvyon yelpaze çökellerindeki temel sondaj çalışmalarında SPT deneyi yapılmıştır. Taşıma gücü hesaplamaları HS-JEOTEK adlı programındaki SPT esaslı yaklaşım ile yapılmıştır (Sönmez, 2004). Çizelge 8'de sondaj kuyularında etkin derinlikteki taşıma gücü ve SPT değerleri gösterilmektedir. Buradaki taşıma gücü temel altında bulunan zeminin herhangi bir yük altındaki etkileşim, kayma ve göçmeye karş1 göstereceği zemin direncini ifade etmektedir.

Çizelge 8. İnceleme alanındaki alüvyal zeminlerin taşıma gücü değerleri.

Table 8. Bearing capacity values of the alluvial soils in the study area.

\begin{tabular}{c|c|c}
\hline Kuyu No & Taşıma Gücü $\left(\mathrm{kgf} / \mathrm{cm}^{2}\right)$ & SPT Darbe Sayıları \\
\hline \multirow{2}{*}{ SK-31 } & & 20 \\
& 0.89 & 17 \\
\multirow{2}{*}{ SK-34 } & & 22 \\
\hline \multirow{3}{*}{ SK-41 } & 0.84 & 9 \\
& & 16 \\
& & 26 \\
\hline \multirow{2}{*}{ SK-42 } & 0.81 & 11 \\
& & 11 \\
\hline \multirow{2}{*}{ SK-58 } & \multirow{2}{*}{0.88} & 6 \\
\hline & & 17 \\
& \multirow{2}{*}{1.62} & 16 \\
\hline
\end{tabular}


Çizelge 8. (devamı)

Table 8. (continued)

\begin{tabular}{|c|c|c|}
\hline SK-62 & 2.57 & $\begin{array}{l}\mathrm{R} \\
\mathrm{R} \\
\mathrm{R}\end{array}$ \\
\hline SK-64 & 2.55 & $\begin{array}{l}\mathrm{R} \\
\mathrm{R} \\
\mathrm{R}\end{array}$ \\
\hline SK-68 & 2.57 & $\begin{array}{l}\mathrm{R} \\
\mathrm{R} \\
\mathrm{R}\end{array}$ \\
\hline SK-69 & 2.56 & $\begin{array}{l}\mathrm{R} \\
\mathrm{R} \\
\mathrm{R}\end{array}$ \\
\hline SK-80 & 2.64 & $\begin{array}{l}\mathrm{R} \\
\mathrm{R} \\
\mathrm{R}\end{array}$ \\
\hline SK-90 & 0.92 & $\begin{array}{l}27 \\
21 \\
16\end{array}$ \\
\hline $\begin{array}{c}\text { SK-92 } \\
\text { (YASS etki derinliği içerisinde) }\end{array}$ & 0.54 & $\begin{array}{l}14 \\
18 \\
12\end{array}$ \\
\hline $\begin{array}{c}\text { SK-23 } \\
\text { (YASS etki derinliği içerisinde) }\end{array}$ & 0.83 & $\begin{array}{l}29 \\
47 \\
36\end{array}$ \\
\hline
\end{tabular}

*R:Refü (İlerleme Yok)

SPT testi sondaj kuyusu içerisinde yapılan, en uçta "boyuna yarık tüp" olarak bilinen standart örnek alıcısının bağlı olduğu tijlerin üzerine, $63.5 \mathrm{~kg}$ ağırlığındaki şahmerdanın 76.2 cm yükseklikten tekrarlı bir şekilde birakılarak kuyu tabanında toplamda $45 \mathrm{~cm}$ 'lik penetrasyon sağlanana kadar çakılması ve bunun için gerekli olan darbe sayısı (SPT/N) değerlerinin belirlenmesi olarak bilinir. SPT testlerinin iri taneli veya kaya gibi zeminlerde ortaya koyduğu sonuçlar sağlıklı olmayabilir. Bununla beraber darbe sayısının azalması zemin taşıma gücünü azaltır. Refü olması ve ilerleme olmaması ise taşıma gücünün yüksek olduğu göstergesidir. İncelenen alanların SPT ve taşıma gücü değerleri ile Çizelge 1'de verilen HRS taşıtlarının zemine uyguladıkları basınçlar açısından değerlendirildiğinde en düşük taşıma gücüne sahip olan kuyu SK-92'dir. Bu noktaya konum olarak en yakın olan nokta ise SK-23 numaralı kuyudur. Her iki kuyuda da etki derinliğinde YASS bulunduğu için benzer SPT değerlerine 
Aydın, Kuşkapan, Çodur

sahip kuyulara nazaran taşıma gücü daha düşük çıkmıştır. Fakat bu iki noktanın taşıma gücü ile SPT değerleri arasındaki ilişki birbiri ile uyumludur.

HRS güzergâhında A noktası olarak belirtilen bölgenin raylı sistem taşıtları açısından zemine uyguladıkları basınç değerleri için yetersiz olduğu görülmektedir. Taşıma gücü değerlerinin hesaplandığı SPT testleri etkili derinliğe kadar değerlendirilmiş olup taşıma gücü değerleri bu deney sonuçlarına göre hesaplanmıştır. İlgili hedefe kadar hesaplanan SPT darbe sayıları aşağılara doğru inildikçe farklılık gösterebildiği için taşıma gücü ile etkili derinlikteki SPT darbe sayılarında farklılıklar söz konusu olabilmektedir. Ayrıca zeminin yapısındaki farklılık ve su içeriği de bu duruma sebep olabilmektedir.

\section{Mikrotremor}

Yeryüzünde gerçekleşen mikro titreşimler o bölgelerde yerin doğal salınımlarını meydana getirir. Zemin farklı fiziksel özellikleri yerin doğal mikro salınımlarını değiştirecektir. Yerin doğal gürültüsünün ayrıca genlik ve frekans içeriklerini, yerin litolojisi ve geometrisi gibi faktörler etkileyecektir. Yerin mikro genlikli doğal salınımları incelenerek yerin etkin salınım periyotları saptanabilir ve bu şekilde yerin davranış özellikleri belirlenebilir. Bu durumda yerin bu doğal salınımlarından faydalanarak elde edilecek parametrelere göre bölgesel olarak zemin sinıflamaları yapılabilir. Mikrotremor kayıtlarının doğru ve gürültülü sinyallerden uzak alınabilmesi ölçüm sonuçlarının doğru olması açısından çok önemlidir. $\mathrm{Bu}$ sebeple ölçümler için araç trafiği ve insan hareketliliğinin en az olacağ sahasında alınan ölçümler Scream 4.4 ve Geopsy yazılımı ile analiz edilerek zemin hakim titreşim periyodu $\left(\mathrm{T}_{0}\right)$ ve zemin büyütmesi $\left(\mathrm{A}_{\mathrm{k}}\right)$ değerleri hesaplanmıştır (Çizelge 9) .
Çizelge 9. Mikrotremor ölçüm sonuçları.

Table 9. Microtremor measurement results.

\begin{tabular}{c|l|l}
\hline Nokta No & $\mathrm{T}_{0}(\mathrm{~s})$ & $\mathrm{Ak}$ \\
\hline $\mathrm{M}-44$ & 0.24 & 2.0 \\
$\mathrm{M}-45$ & 0.15 & 1.9 \\
$\mathrm{M}-47$ & 0.32 & 1.9 \\
$\mathrm{M}-53$ & 0.24 & 1.6 \\
$\mathrm{M}-54$ & 0.13 & 1.9 \\
$\mathrm{M}-56$ & 0.08 & 1.1 \\
$\mathrm{M}-62$ & 0.24 & 1.4 \\
$\mathrm{M}-65$ & 0.16 & 1.9 \\
$\mathrm{M}-70$ & 0.16 & 1.2 \\
$\mathrm{M}-71$ & 0.12 & 1.4 \\
$\mathrm{M}-72$ & 0.11 & 1.1 \\
$\mathrm{M}-78$ & 0.16 & 1.6 \\
M-79 & 0.83 & 4.0 \\
\hline
\end{tabular}

\section{BULGULAR}

Uygulama alanında; alüvyon tabakas1 derinliğinin fazla olması, yeraltı su seviyesinin yüzeye yakın olması sismik kırılma çalışmasıyla $\mathrm{S}$ dalgasının üretilmesini zor hale getirmiştir. Araştırma derinliğinin sığ kalarak alüvyal tabaka içerisinde yer alması; düşük frekanslarda uzun dalga boyları ile seyahat eden daha derinlerden bilgi taşıyan ve altta bulunan gevşek zonların tespitini kolaylaştıran aktif kaynaklı yüzey dalgası yöntemi (MASW) kullanılarak yer altı yapısının ortaya çıkarılmasını teknik bir zorunluluk haline getirmiştir. $\mathrm{Bu}$ doğrultuda HRS güzergâhına ilişkin $\mathrm{V}_{\mathrm{S} 30}$ haritası Şekil 7'de gösterilmektedir.

Alana ilişkin hazırlanan $\mathrm{V}_{\mathrm{s} 30}$ haritasında güzergâh planının başladığ1 $\mathrm{A}$ noktasında $\mathrm{V}_{\mathrm{s} 30}$ hizının $180-220 \mathrm{~m} / \mathrm{s}$ arasında olduğu, B ve C noktalarında ise $280-300 \mathrm{~m} / \mathrm{s}$ arasında olduğu gözlenmektedir. Sismik hızlar incelendiği zaman $A, B$ ve $C$ noktalarında düşük hızlar ile seyrettiği gözlenmektedir. Burada bulunan zeminin fiziksel parametrelerinden bir veya birkaçının 
irdelenmesi gerektiğini göstermektedir. Aşağıda Çizelge 10'da Türkiye Bina Deprem Yönetmeliği (TBDY) verilerine göre $\mathrm{V}_{\mathrm{s} 30}$ hiz sinıflandırma tanımları gösterilmektedir.

HRS çalışma alanında $\mathrm{V}_{\mathrm{s} 30}$ hızı genel olarak 260 ile $360 \mathrm{~m} / \mathrm{s}$ arasında değişmektedir. TBDY (2018)'e göre bu alan ZD yani orta s1k1 - s1k1 kum, çakıl veya çok katı kil tabakaları sınıfında yer almaktadır. $\mathrm{Bu}$ durumla uyumlu olarak Şekil 1'deki görselde de belirtildiği üzere HRS güzergâhı Erzurum Ovası içerisinde alüvyal malzemeler üzerinde yer almaktadır. Erzurum yerleşim merkezinin jeoloji haritasında da görülebileceği gibi havza içerisinde olması günümüze değin yapılan imar planlarına esas jeolojik çalışmalarda, parsel bazlı zemin etüdü çalışmalarında ana kaya tespit edilememesinin sebeplerindendir.Erzurum İli ana kaya derinliği yapılan gravite çalışmalarında kilometreler ile ifade edilmektedir. Fakat bunu doğrulayacak derin sondajlar günümüze değin şehir merkezinde yapılmamıştır. $\mathrm{Bu}$ bilgiler doğrultusunda çalışma sahası taşınan ve biriken alüvyal malzemeler üzerindedir.
Ana kaya olmaması ve ana kaya üzerinde bu kadar kalın alüvyal olması sismik hızların düşük seyretmesine sebep olmaktadır. Ayrıca alanda buluna yer altı suyu varlığı, hızların bu bölümlerde daha da düşmesine sebep olmaktadır.

Bir bölgedeki titreşimler, o bölgelerde zeminindoğal gürültüsünü oluşturmaktadır. Farklı zemin koşullarına göre zeminin doğal gürültüsü de farklı olacaktır. Zeminin doğal gürültüsünün genlik ve frekans içeriklerini, yerin litolojisi ve geometrisi gibi faktörler etkileyecektir. Zeminin çok küçük genlikli doğal salınımları incelenerek etkin salınım periyotları saptanabilir ve bu şekilde davranış özellikleri belirlenebilmektedir. $\mathrm{Bu}$ durumda zeminin doğal titreşimlerinden yararlanılarak elde edilecek parametrelere göre bölgesel olarak zemin siniflamaları yapılabilmektedir. $\mathrm{Bu}$ amaçla çalışma hafif raylı tren güzergâhına isabet eden bölgede hazırlanan mikrotremor ölçümler alınmıştır. Elde edilen ölçümler neticesinde alana ilişkin zemin hakim titreşim periyodu ve zemin büyütme değeri haritaları oluşturulmuştur (Şekil 8).

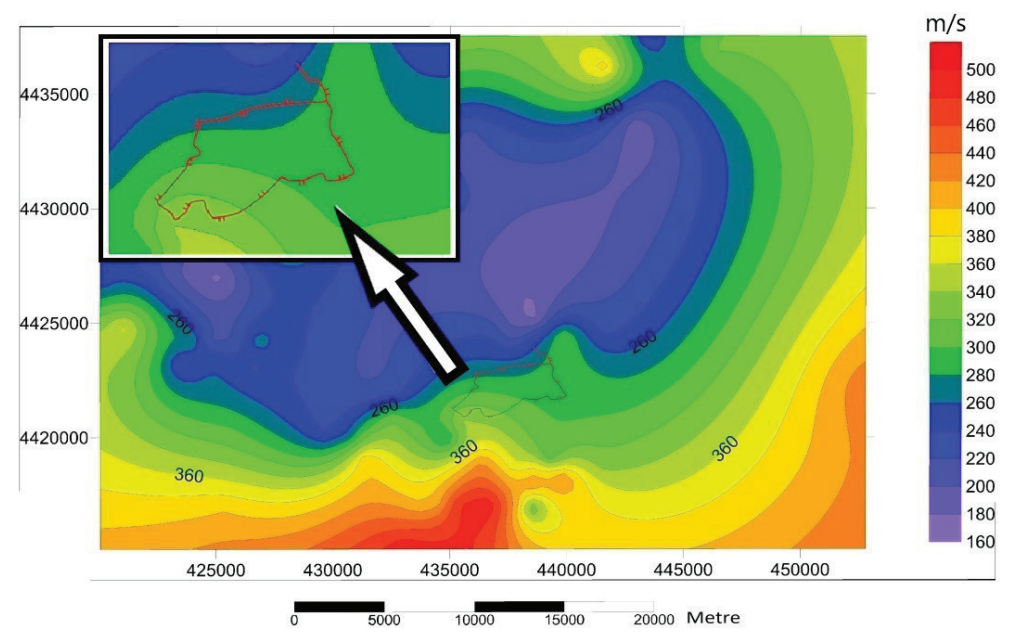

Şekil 7. HRS güzergâh planı ve alana ilişkin $\mathrm{V}_{\mathrm{s} 30}$ haritası.

Figure 7. LRS route plan and $V_{s 30}$ map of the area. 
Aydın, Kuşkapan, Çodur

Çizelge 10. TBDY'ye göre $\mathrm{V}_{\mathrm{s} 30}$ hız sinıflaması (TBDY, 2018).

Table 10. $V_{\text {s30 }}$ velocity classification according to TBDY (TBDY, 2018).

\begin{tabular}{|c|c|c|}
\hline Zemin Sinıfi & Tanım & $\begin{array}{c}\text { Üst } 30 \text { Metre } \\
\left.\text { Ortalama }\left(\mathrm{V}_{\mathrm{s} 30}\right) \mathrm{m} / \mathrm{s}\right)\end{array}$ \\
\hline $\mathrm{ZA}$ & Sağlam ve sert kayalar & $\mathrm{V}_{\mathrm{s}}>1500$ \\
\hline ZB & Az ayrışmış orta sağlam kayalar & $760<\mathrm{V}_{\mathrm{s}}<1500$ \\
\hline $\mathrm{ZC}$ & $\begin{array}{l}\text { Çok sıkı kum, çakıl ve sert kil tabakaları veya ayrışmış, çok çatlaklı zayıf } \\
\text { kayalar }\end{array}$ & $360<\mathrm{V}_{\mathrm{s}}<760$ \\
\hline ZD & Orta sık1 - sık1 kum, çakıl veya çok katı kil tabakaları & $180<\mathrm{V}_{\mathrm{s}}<360$ \\
\hline ZE & $\begin{array}{c}\text { Gevşek kum, çakıl veya yumuşak - katı kil tabakaları veya PI > } 20 \text { ve w } \\
>\% 40 \text { koşullarını sağlayan toplamda } 3 \text { metreden daha kalın yumuşak kil } \\
\text { tabakası }(\mathrm{cu}<25 \mathrm{kPa} \text { ) içeren profiller }\end{array}$ & $\mathrm{V}_{\mathrm{s}}<180$ \\
\hline $\mathrm{ZF}$ & $\begin{array}{l}\text { Sahaya özel araştırma ve değerlendirme gerektiren zeminler: } \\
\text { 1) Deprem etkisi altında çökme ve potansiyel göçme riskine sahip zeminler } \\
\text { (sıvılaşabilir zeminler, yüksek derecede hassas killer, göçebilir zayıf } \\
\text { çimentolu zeminler vb.), } \\
\text { 2) Toplam kalınlığ } 3 \text { metreden fazla turba ve/veya organik içeriği yüksek } \\
\text { killer, } \\
\text { 3) Toplam kalınlığı } 8 \text { metreden fazla olan yüksek plastisiteli (PI >50)killer, } \\
\text { 4) Çok kalın }(>35 m) \text { yumuşak veya orta katı killer. }\end{array}$ & \\
\hline
\end{tabular}

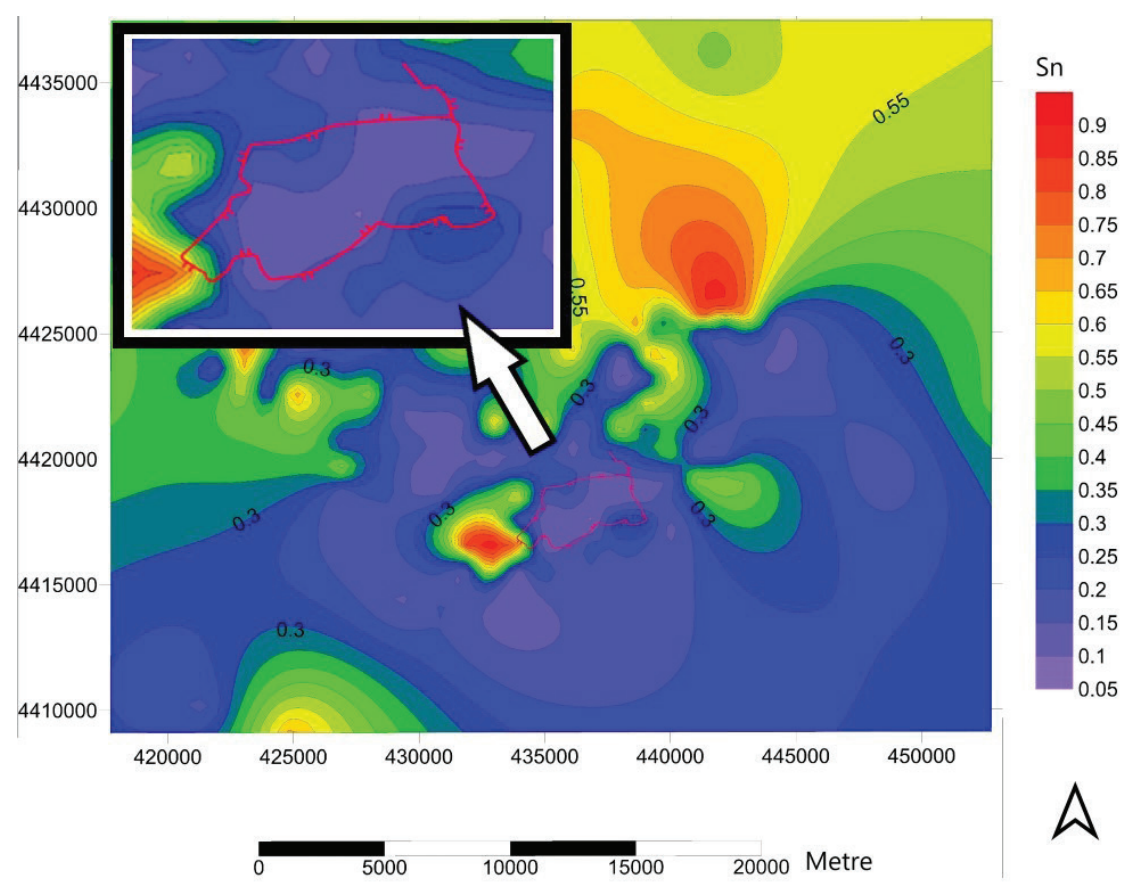

Şekil 8. HRS güzergah planı ve alana ilişkin zemin hakim titreşim periyodu haritası.

Figure 8. LRS route plan and soil dominant vibration period map of the area. 
Şekil 8'de bulunan zemin hakim titreşim periyodu incelendiğinde $\mathrm{B}$ noktasında 0.80 $\mathrm{s}, \mathrm{C}$ noktasında $0.5 \mathrm{~s}$ değeri gösteren yüksek periyotlar gözlenmektedir. $\mathrm{Bu}$ alanın fiziksel parametrelerinden biri veya birkaçında çeşitli sorunlara işaret etmektedir. Bununla beraber D-E aksında zemin hakim titreşim periyodu $0.05-0.25$ $\mathrm{s}$ aralığında düşük salınımlar göstermektedir. $\mathrm{Bu}$ düşük değerlerde bu bölgede bulunan zeminlerin fiziksel parametrelerinin diğer noktalara göre yüksek dayanıma sahip olduğunu işaret etmektedir. Şekil 9'da bulunan zemin büyütme haritası incelendiğinde B noktasında 3.6 - 3.8 aralığında zemin büyütme değeri gözlenmekte ve bu da zeminin fiziksel parametrelerinin irdelenmesi gerektiğini ifade etmektedir. D - E aksı incelendiğinde zemin büyütme değeri $1-1.4$ aralığındadır.

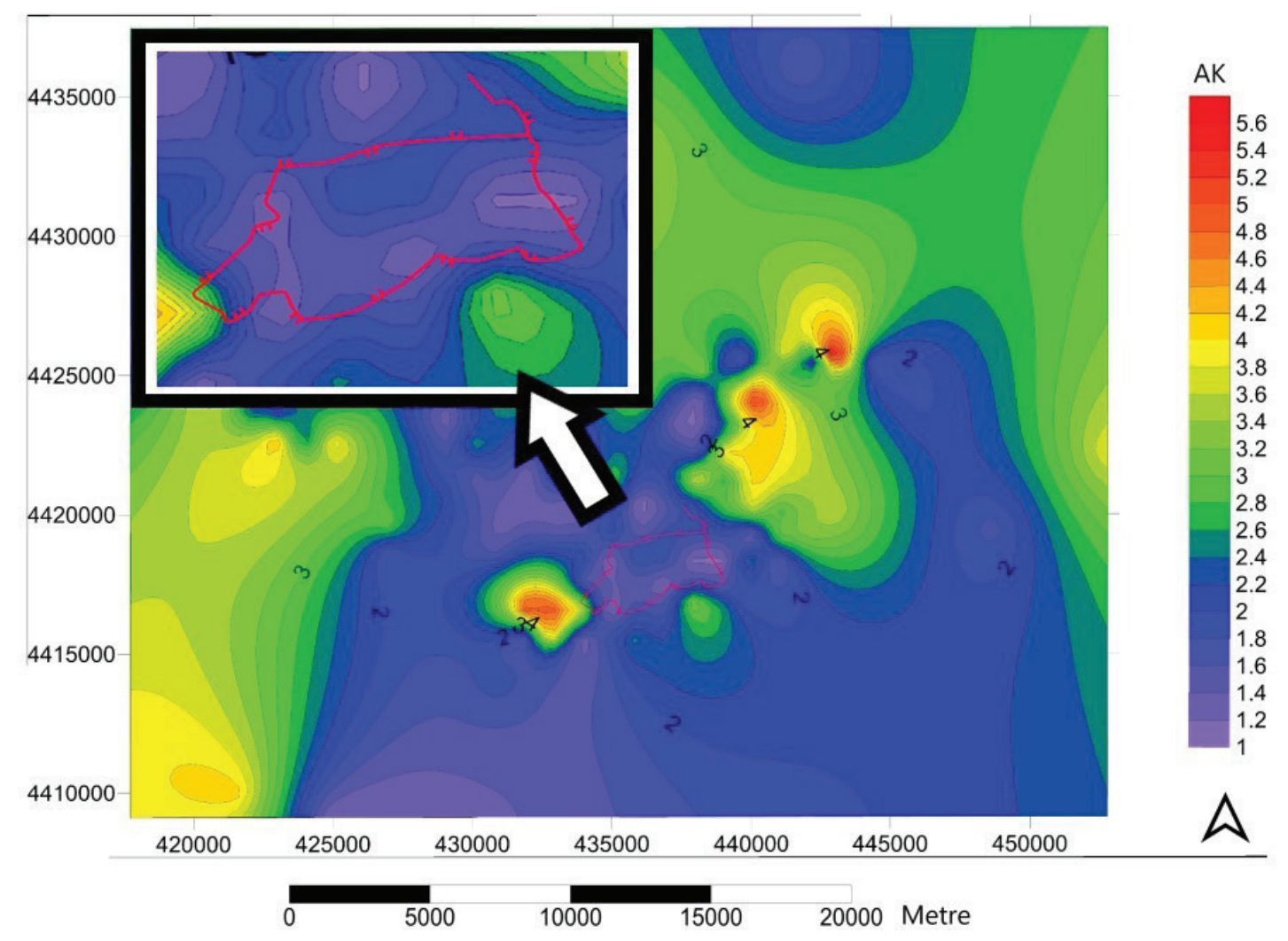

Şekil 9. HRS güzergâh planı ve alana ilişkin zemin büyütme değeri (Ak) haritası.

Figure 9. LRS route plan and soil amplification (Ak) map of the area. 
Aydın, Kuşkapan, Çodur

Jeolojik incelemelerde uydu görüntüleri ile destekli Coğrafi Bilgi Sistemlerinin kullanılması yapılan incelemelerin güçlendirilmesi adına çok önemlidir. Bununla birlikte Google Earth programının sunmuş olduğu güncel uydu görüntüleri sayesinde yapılan çalışma alanı daha detaylı incelenebilmektedir (Tekin ve Sagular, 2016). HRS güzergâhında A noktas1 olarak belirlenen bölge günümüzde aktif olarak kullanılmakta olan şehirlerarası tren garının yanında bulunmaktadır. B, C ve D noktaları ise Erzurum Şehir Hastanesi ve Bölge Eğitim
Araştırma Hastanesine 600 metre uzaklıkta yer almaktadırlar. E noktası ise şehirleşmenin arttığ1 ve TOKİ konutlarına yakın bölgede bulunmaktadır.

Şekil 10'da gösterimi bulunan haritada zemin büyütme değerleri ile çizilen zemin büyütme haritası, uydu haritası ile üst üste çakıştırılmıştır ve HRS güzergâhı üzerine eklenmiştir. Bu şekilde hem büyütme değerlerini, hem güzergâh çalışma alanının uydu görüntüsü ile beraber inceleme firsatı sunmaktadır.

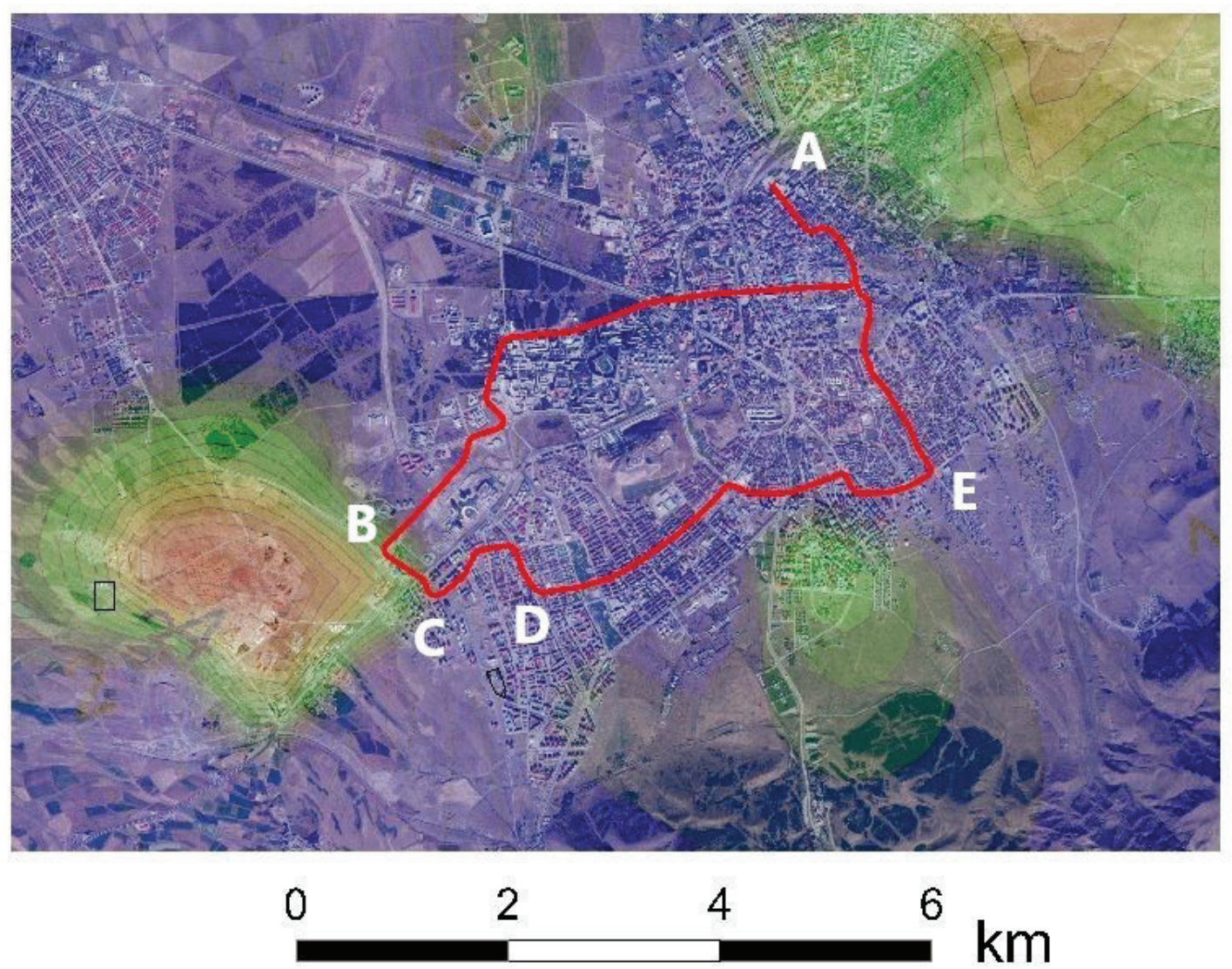

Şekil 10. Uydu görüntüsü üzerinde HRS güzergâh planı ve alana ilişkin zemin büyütme değeri (Ak) haritası. Figure 10. LRS route plan and soil amplification value (Ak) map of the area on the satellite view. 


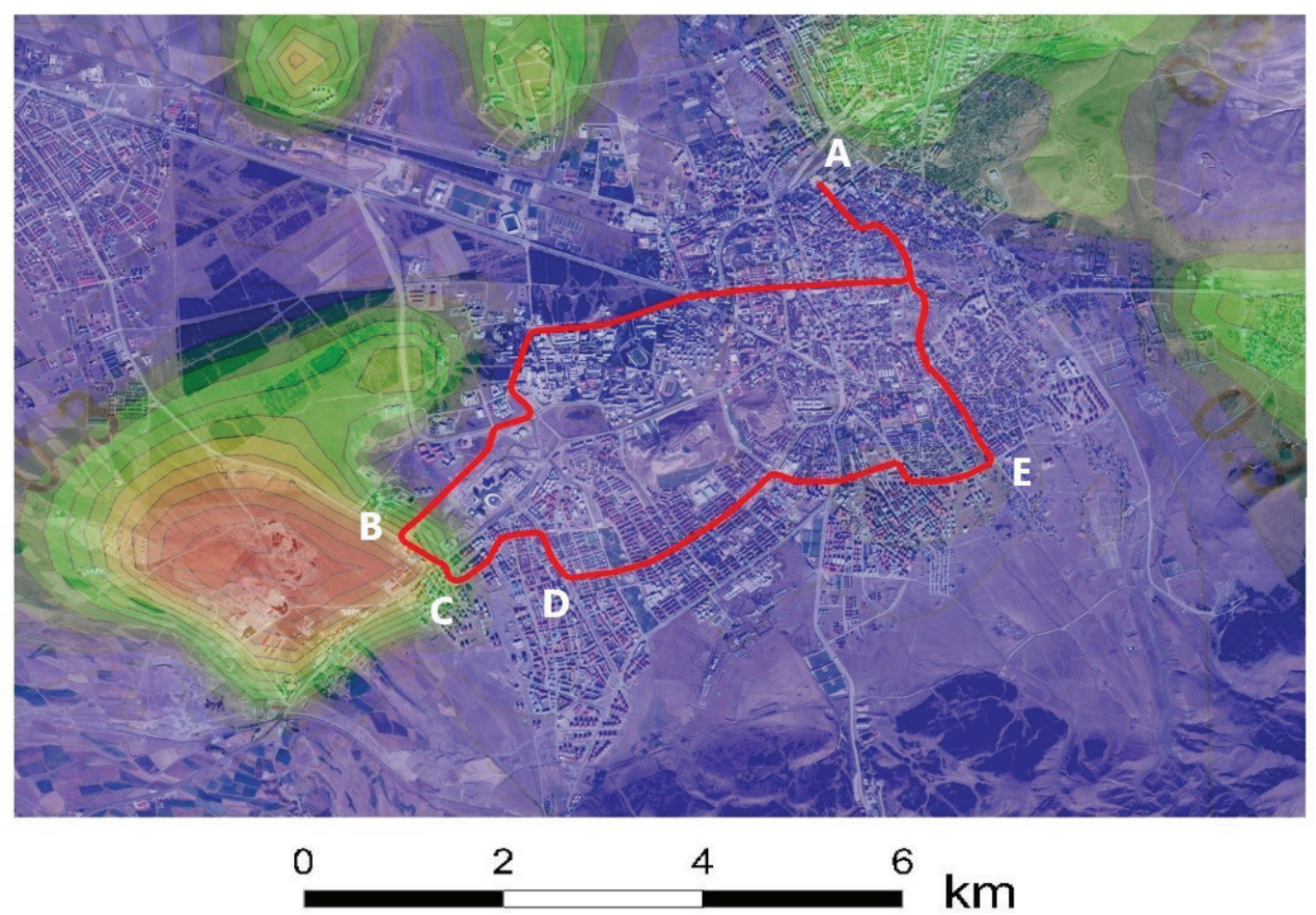

Şekil 11. Uydu görüntüsü üzerinde HRS güzergah planı ve alana ilişkin zemin hakim titreşim periyodu haritası.

Figure 11. LRS route plan and soil dominant vibration period map of the area on the satellite view.

Zeminde doğal (deprem, heyelan vs) veya çeşitli sebeplerden salınım meydana geldiğinde bu dalgalar yerin içerisinde farklı hızlarda yayılmaya başlarlar. $\mathrm{Bu}$ dalgalar yeryüzüne yayıldıkları da saniyelerden dakikalara kadar sürebilecek titreşimler meydana getirirler. Belirli bir alandaki dalganın oluşturduğu titreşimin süresi ve şiddeti; depremin büyüklüğüne, kaynaktan uzaklığına ve dalgaların yol aldığ zeminin fiziksel parametrelerine bağlidır (Akıl vd., 2008). Zemin tabakaları birer dalga filtresi veya dalga katsayısını artıran bir güç alanı gibidir. Bazı frekanstaki sismik dalgalar sönümlenirken bazılarının da genlikleri artmaktadır. Sismik dalgaların zemin tabakaları içerisindeki değiştirdiği değişimlerin tümü zemin etkisi olarak nitelendirilmektedir. Genliklerini artırıc1 özellikte olan güç alanı gibi çalışarak dalgaların genliğini artıran bu alanlara zemin büyütme alan1, büyütme katsayısı da zemin büyütme olarak nitelendirilir. Şekil 10'da bulunan zemin büyütme haritası incelendiğinde $\mathrm{B}$ ve $\mathrm{C}$ noktalarında meydana gelebilecek herhangi bir salınım zeminin dalgaları büyütme özelliğinden belirlenen katsayılarda genliği artırabileceği, Şekil 11'de bulunan zemin hakim titreşim periyodu haritası incelendiğinde ise yine $\mathrm{B}$ ve $\mathrm{C}$ noktalarında hakim titreşim periyotunun yüksek değerler gösterdiği bu alanlarda olası dalgaların periyotlarının yüksek değerler göstereceği gözlenmektedir.

A noktasina yakın konumda bulunan ve en düşük taşıma gücüne sahip 92 numaralı sondaj kuyusunun sıvılaşma potansiyeli logu Şekil 12'de sunulmuştur. 
SIVILAŞMA POTANSIYELI DEĞERLENDIRMESi

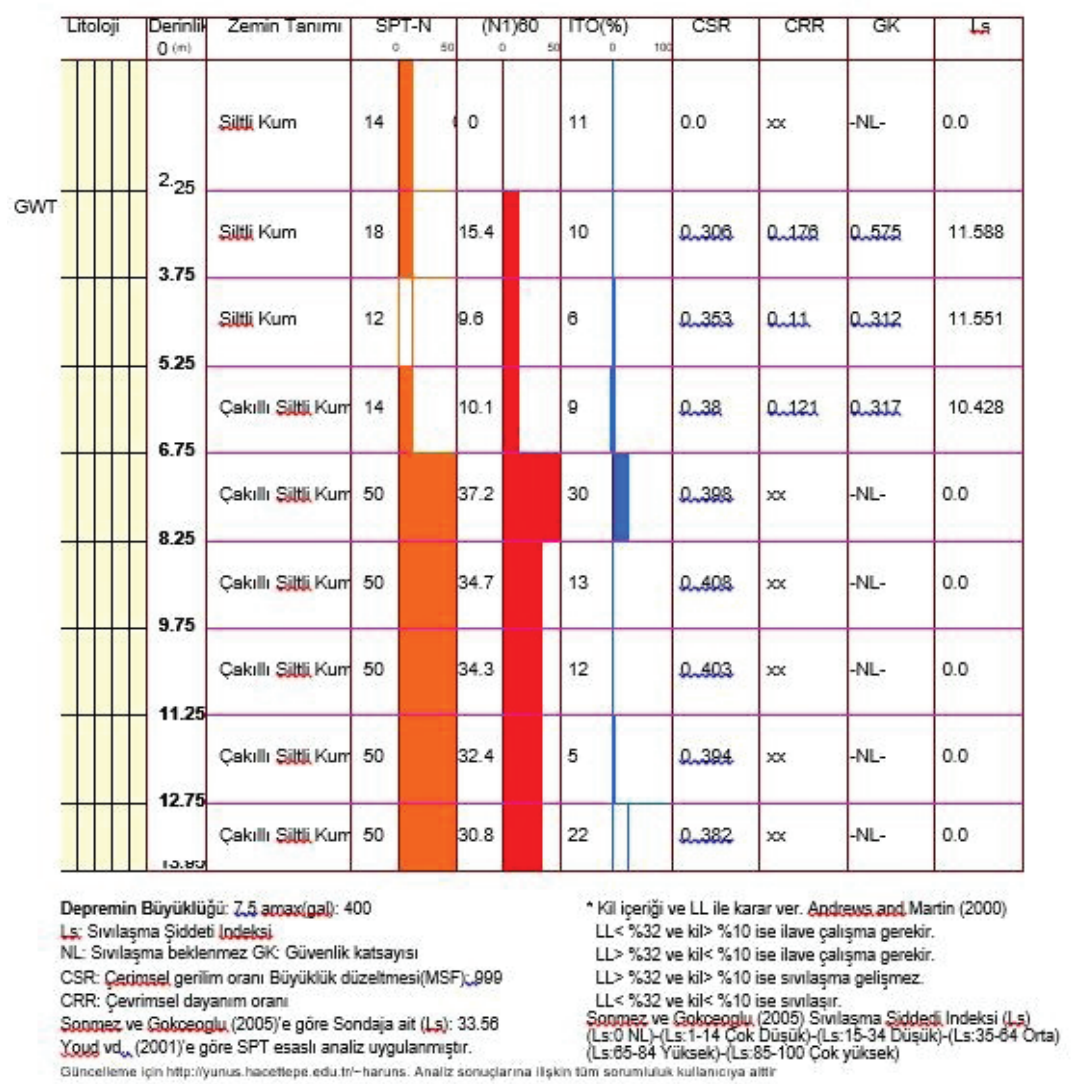

Şekil 12. SK-92 numaralı kuyunun sıvılaşma potansiyeli logu.

Figure 12. Liquefaction potential log of borehole SK-92.

Sunulan logda ilk tabakada sıvılaşma şiddet indeksi 0 olmakla beraber YASS sinırlarında sıvılaşma potansiyeli yükselmektedir. Sondaj kuyularından alınan numunelerin zemin mekaniğ $i$ laboratuvar testlerinde su içeriği 26.2 olarak hesaplanıp siltli kum olduğu tespit edilmiştir. Ayrıca bu noktada $2.25 \mathrm{~m}$ derinliğinde yer altı su seviyesi sebebiyle sıvılaşma potansiyelinin bulunduğu gözlenmiştir. Yeraltı su seviyesinin zemine bu kadar yakın raylı sistem hattı üzerinde küçük deformasyonlara sebep olabilme ihtimalini taşımaktadır. Raylı sistemler üzerindeki küçük deformasyonlar ise büyük problemleri meydana getirebilmektedir.

B ve C noktaları arasında bulunan SK-58 numaralı kuyuya ait sıvılaşma potansiyeli logu ise Şekil 13'te verilmektedir. Sondaj kuyularından alınan numunelerin zemin mekaniği laboratuvar testlerinde su içeriği \%20.8 olarak hesaplanan siltli kum-iyi derecelendirilmiş çakıllı kum olduğu tespit edilmiştir. 


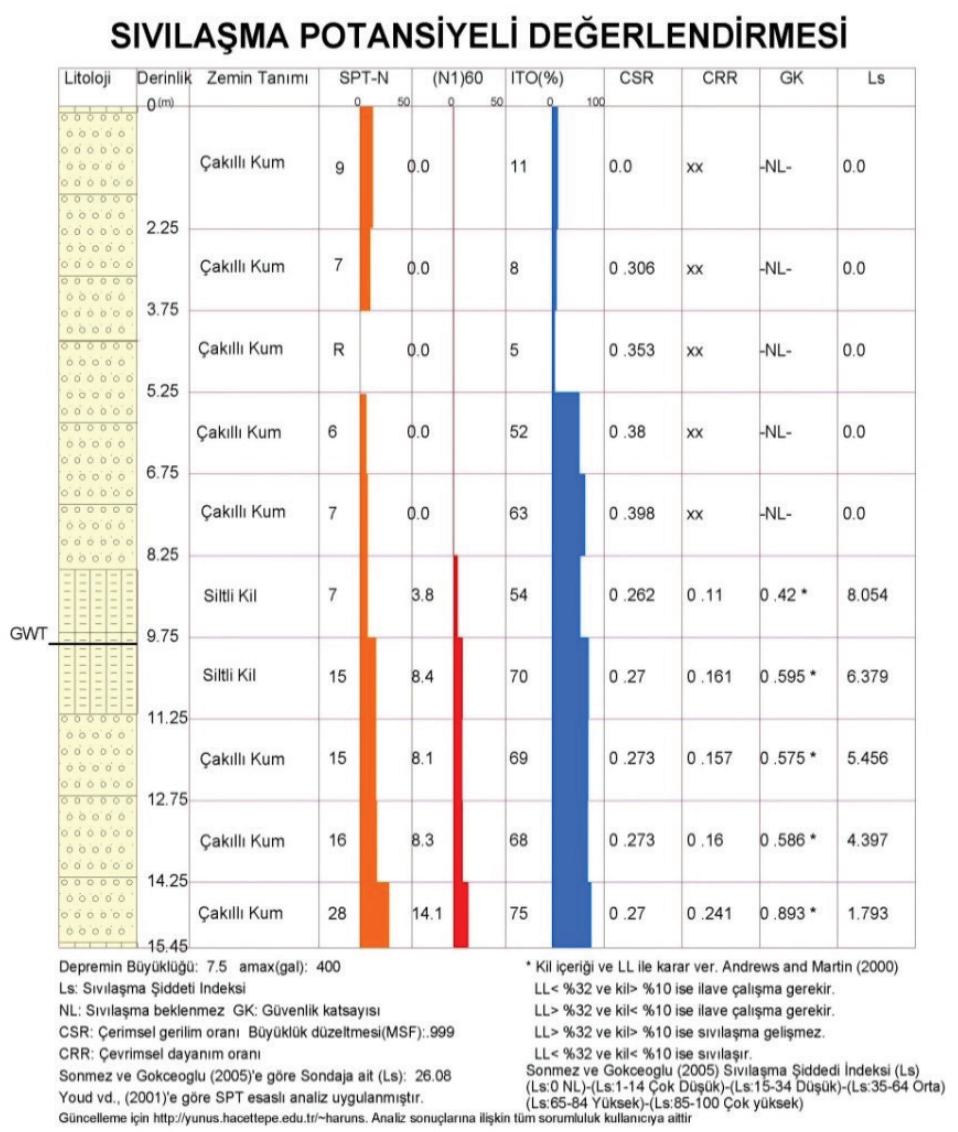

Şekil 13. SK-58 numaralı kuyunun sıvılaşma potansiyeli logu.

Figure 13. Liquefaction potential log of borehole SK-58.

$\mathrm{Bu}$ bölgede zeminde taşıma gücü yeterli olsa da zeminin hakim salınımlarının genlik spektrumlarıileçıkarılan zeminbüyütme değerive zemin hakim titreşim periyodu yüksek çıkmıştır. Taşıma gücünün yüksek olması zeminin yüzeye yakın tabakalarının çakıllı kum olmasından ileri gelebileceği fikrini göz önüne getirmektedir. Bununla beraber alanda hazırlanan $\mathrm{Ak}$ ve ZHTP (zemin hakim titreşim periyodu haritası) haritalarında zeminin fiziksel özelliklerinde problemler gözlenmektedir. Zemindeki sorununun yeraltı suyundan ve buna bağlı olarak zeminin rijitite sorunlarından kaynaklanabileceği düşünülmektedir. Bununla beraber söz konusu bölgenin YASS $9.80 \mathrm{~m}$ derinliğindedir. Bununla beraber sıvılaşma şiddeti indeksi bu derinlikte siltli kum formasyonu ile artmaktadir. Bu durum Ak ve ZHTP haritalarında bu bölge için olumsuz zemin özelliklerinin 9 metre sonrası bulunan YASS ve sıvılaşma şiddeti indeksinin yüksek olduğundan olabileceği düşünülmektedir.

D-E doğrultusu yani doğu - batı aks1 incelendiğinde bu hat üzerine denk gelen zemin büyütme değerleri 1.0 - 1.4 katsayısı aralığında, zemin hakim titreşim periyodu ise $0.05-0.25 \mathrm{~s}$ aralığında düşük değerler gösteren stabil alanları ifade ederken, $\mathrm{V}_{\mathrm{S} 30}$ sismik hizları 320-360 m/s 
Aydın, Kuşkapan, Çodur

yüksek değerler gösteren masif, katı ve sert formasyonları ifade etmektedir.

Şekil 14'te ise belirtilen durumlar göz önünde bulundurularak mevcut güzergâhın zemin yapısina uygun olmayan noktaları revize edilerek oluşturulmuş alternatif güzergâh gösterilmektedir.

Mevcut güzergâh üzerinde bulunan B ve C noktaları zemin emniyeti açısından uygun olmadığ1 için bu noktaları güzergâh dışında bırakacak alternatif bir güzergâh planlanmıştır. Alternatif güzergâhların belirlenmesi zemin emniyeti çok önemlidir. Bazı koşullarda alternatif güzergâhların bulunamama durumu söz konusu olabilmekte veya oluşabilen güzergâh daha kötü zemin özellikleri içerebilmektedir (Seyitoğlu vd., 2016). Ulaşım alanında alternatif güzergâh planlama işleminde; yolcu talebinin yüksek olması beklenen Erzurum Şehir Hastanesi ve
Bölge Eğitim Araştırma Hastanesi ön planda tutulmuştur. Mevcut güzergâhta $\mathrm{B}$ ve $\mathrm{C}$ noktaları bu iki hastaneye biraz daha uzak konumda olduğu için yolcu memnuniyetini düşürebilmektedir. Çünkü bu bölgeye ulaşım sağlamak isteyen personeller, hastalar ve hasta yakınlarının en kısa mesafede hastaneye ulaşımları; hizmet kalitesi ve insan sağlığı adına da çok önemlidir. $\mathrm{Bu}$ doğrultuda alternatif güzergâhta HRS hattı $\mathrm{B}$ ve $\mathrm{C}$ noktaları yerine hastaneler bölgesine yakınlaştırılmıştır. Diğer bir problemli nokta olan A noktası ise tren ve HRS için önemli bir aktarma noktasıdır. Bu sebeple A noktasının değiştirilme durumu yolcu talebini düşürebilmektedir. Yolcu talebini karşılamak amacıyla bu nokta için zemin iyileştirilmesi yapılması daha uygun olmaktadır. Sonuç itibariyle $\mathrm{B}$ ve $\mathrm{C}$ noktalarının revize edilmesi ve A noktasının güçlendirilmesi ile zemin güvenliği yüksek ve yolcu talebine daha uygun bir güzergâh elde edilmiştir.

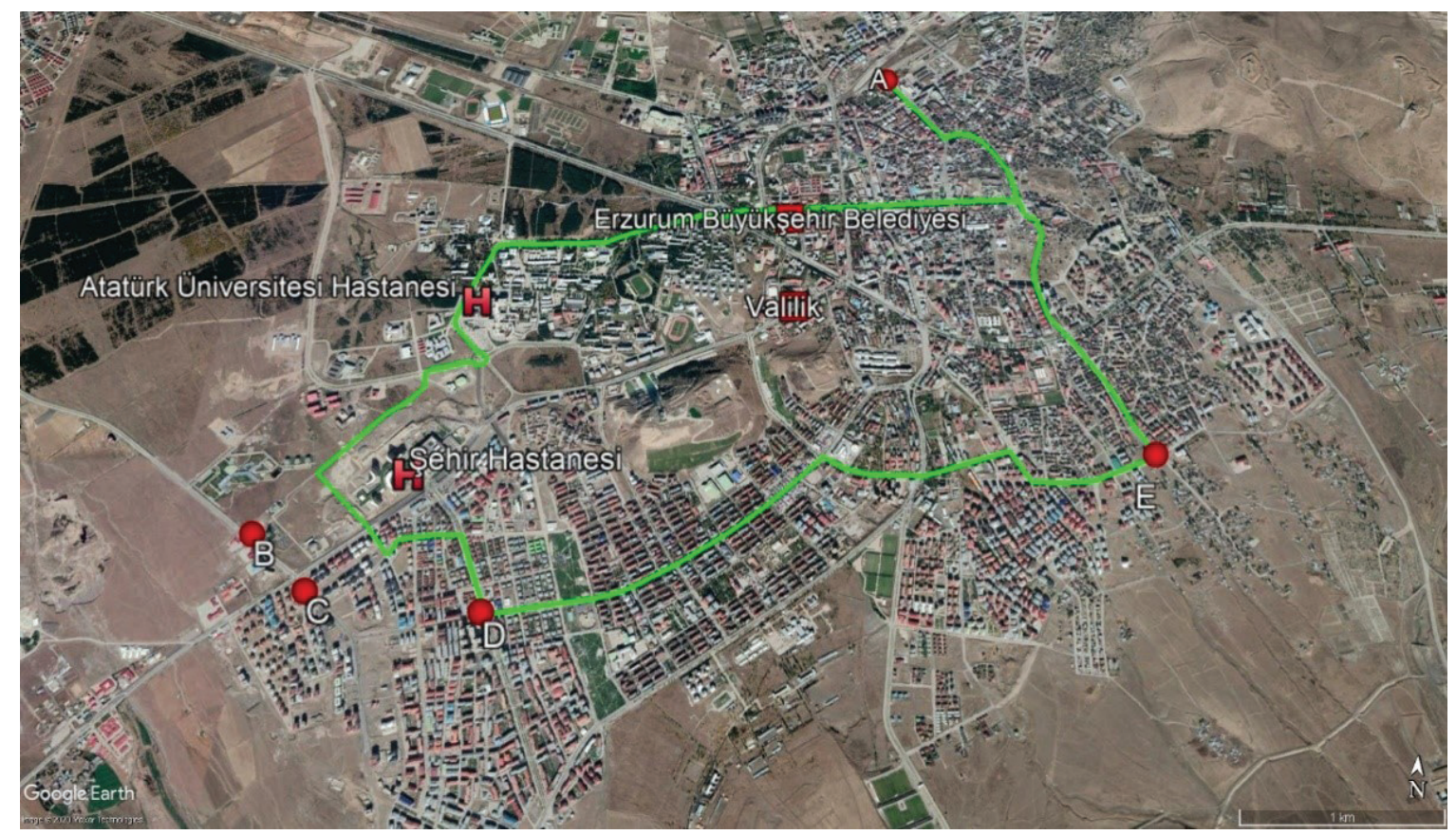

Şekil 14. HRS için zemin durumuna uygun olarak önerilen alternatif güzergâh.

Figure 14. An alternative route recommended for LRS in accordance with the ground condition. 


\section{SONUÇLAR VE TARTIŞMA}

Yapılan bu çalışma sonucunda HRS güzergâh1 üzerinde bulunan $\mathrm{A}, \mathrm{B}$ ve $\mathrm{C}$ noktalarında zemine ilişkin hızların düşük olması, su içeriği, yeraltı su seviyesi gibi bazı sorunlar olduğu tespit edilmiştir. Bu noktalarda zemin büyütme katsayısı ile zemin hakim titreşim periyodu yüksek değerler göstermektedir. Bu noktalarda ortaya çıkan bu fiziksel sorunları ayrıntılı incelemek için alanda yapılan diğer etüt ve deneyler incelenmiştir.

Hazırlanacak olan uygulama projelerinden öncelikle $\mathrm{A}, \mathrm{B}$ ve $\mathrm{C}$ noktalarının bulunduğu alanlarda detaylı inceleme yapılarak A noktası için geoteknik iyileştirme projesi hazırlanması, $\mathrm{B}$ ve $\mathrm{C}$ noktaları için güzergâh revize edilmesi gerekliliği ortaya çıkmaktadır. B-C noktalarında geoteknik iyileştirme projesinin önerilmemesi ve güzergâhta revizeye gidilmek istenilmesinin temelinde zemin özellikleri ile beraber alanın ulaşım talebi de göz önüne alınmıştır. Çünkü yeni yapılmış olan Erzurum Şehir Hastanesinin hemen bitişiğine taşınmış olan bu HRS hat kesimi; hem bu bölgede çalışan bireylerin hem de hasta ve hasta yakınlarının hastaneye erişimlerinin kolaylaşması amacını gütmektedir. Benzer şekilde A noktası ise tren garının bitişiğinde olduğu için başlangıç durağının revize edilmemesi ve yolcu aktarma işlemlerinin hızlı şekilde sağlanması ulaşım adına daha uygun olacaktır. Bu doğrultuda revize edilecek olan HRS güzergâhına ait zemin problemlerinin minimize edilmesi, söz konusu olabilecek deformasyonlardan kaynaklı raylı sistem kazalarının önüne geçilmesi ve HRS taşıtlarının yolcu memnuniyetinin artırılması sağlanacaktır. Yapılan bu çalışma ile herhangi bir raylı sistem güzergâhı belirlenirken zemin özelliklerinin araştırılması ve güzergâhın bu zemine uygun hale getirilmesinin gerekliliği ortaya konmuştur.

\section{KATKI BELİRTME}

$\mathrm{Bu}$ çalışmada verilerin temin edilme sürecinde desteklerini esirgemeyen Erzurum Büyükşehir Belediyesi’ne teşekkürlerimizi sunariz.

\section{KAYNAKLAR}

Akıl, B., Akpınar, K., Üçkardeşler, C., 2008. Doğu Anadolu fay zonu üzerinde yer alan Gölbaş1 (Adıyaman) yerleşim alanındaki zeminlerin jeoteknik özellikleri ve değerlendirilmesi. Türkiye Jeoloji Bülteni, 51 (1), 43-57.

Altınlı, İ.E., 1963. 1:500 000 ölçekli Türkiye jeoloji haritas1, Erzurum paftası izahnamesi: MTA Yayınları, 131, Ankara.

Argyroudis, S., Kaynia, A.M., 2014. Fragility functions of highway and railway infrastructure. Geotechnical, Geological and Earthquake Engineering, 27, 300-326.

Baştürk, G., 2014. Kent içi raylı toplu taşıma sistemleri incelemesi ve dünya örnekleri ile karşılaştııılması. Ulaştırma ve Haberleşme Uzmanlığı Tezi, Ankara, 120s.

Bergquist, B., Söderholm, P., 2014. Data analysis for condition-based railway infrastructure maintenance. Quality and Reliability Engineering International, 31, 773-781.

Bozankaya, 2020. https://www.bozankaya.com.tr/ tramvay/ 1 Şubat 2020.

Burulaş, 2020. https://www.burulas.com.tr/tramvayarac-ozellikleri.aspx, 2 Şubat 2020.

BSSC (Building Seismic Safety Council), 1997. NEHRP-Recommended Provisions for Seismic Regulations for New Buildings and Other Structures, Part 1: Provisions and Part 2: Commentary, prepared by the Building Seismic Safety Council for the Federal Emergency Management Agency (Report Nos. FEMA 302 and 303), Washington, D.C.

Candemir, I., Tanyel, S., 2005. Hızlı raylı sistemlerin yolcu taşıma kapasite hesaplamaları ve Türkiye'deki benzer sistemlerin birbirleriyle 
Aydın, Kuşkapan, Çodur

karşılaştırılması. 6. Ulaştırma Kongresi; 23-25 May1s 2005, İstanbul, 309-322.

Cui, S., Guo, C., Su, J., Cui, E., Liu, P., 2019. Seismic fragility and risk assessment of high-speed railway continuous-girder bridge under track constraint effect. Bulletin of Earthquake Engineering, 17, 1639-1665.

Dikmen, Ü., Başokur, A.T., Akkaya, İ., Arısoy, M.Ö., 2009. Yüzey dalgalarının çok-kanallı analizi yönteminde uygun atış mesafesinin seçimi. Yerbilimleri, 31 (1), 23-32.

Durmaray, 2020. http://www.durmaray.com/ipekbocegitramvay/2/3/5 1 Şubat 2020

Erentöz, C., 1949. Hınıs 65/2 paftasının raporu: MTA, Derleme rapor no. 2159 (yayımlanmamış).

Erdoğan, Ç., 2011. Kocaeli hafif raylı taşıma sistemi fizibilite raporu. İstanbul Teknik Üniversitesi, Fen Bilimleri Enstitüsü, İstanbul, Yüksek Lisans Tezi, 227s.

Erdoğan, T., Soytürk, N., 1974. Tekman baseni jeolojisi ve hidrokarbon imkânları raporu : TPAO, Arama Grubu Başkanlığı Raporu, 870, 20, Ankara.

Erzurum Büyükşehir Belediyesi, 2018. https://www. erzurum.bel.tr/ebb-aykome-ice/1005/24038/H. html, 12 Ocak 2020.

Gündüz, A.Y., Kaya, M., Aydemir, C., 2011. Kentiçi ulaşımında karayolu ulaşımına alternatif sistem: raylı ulaşım sistemi. Akademik Yaklaşımlar Dergisi, 2 (1), 134-151.

Harami, A., Furlan, R., 2020. Qatar National MuseumTransit oriented development: The master plan for the urban regeneration of a 'green TOD'. Journal of Urban Management, 9, 115-136.

Kaya, A., 2005. Selçuk Üniversitesi Alaaddin Keykubat Kampüsü hafif raylı ulaşım sistemi uygulama projesi ve değerlendirilmesi. Selçuk Üniversitesi Fen Bilimleri Enstitüsü, Konya, Yüksek Lisans Tezi, 120s.

Kolos, A., Taczanowski, J., 2016. The feasibility of introducing light rail systems in medium-sized towns in Central Europe. Journal of Transport Geography, 54, 400-413.
Maden Tetkik ve Arama Genel Müdürlüğü (MTA). 2003. https://www.mta.gov.tr/v3.0/hizmetler/ jeoloji-haritalari, 14 Ocak 2020.

Mercier, J., 1948. Hinıs 65/2 paftasinın raporu: MTA, Derleme rapor no. 2258 (yayımlanmamış).

Murteza, M., 2010. Raylı sistem yatırımları fizibilite etütleri ve yapım yöntemleri. Bahçeşehir Üniversitesi Fen Bilimleri Enstitüsü, İstanbul, Yüksek Lisans Tezi, 71s.

Ocak, İ., Manisalı, E., 2006. Kentsel raylı taşıma üzerine bir inceleme (İstanbul örneği). Sakarya Üniversitesi Fen Bilimleri Enstitüsü Dergisi, 10 (2), 51-59.

Önder, H.G., Akdemir, F., 2019. Türkiye'deki kentiçi raylı toplu taşıma sistemlerinin ulaşım ana planları bağlamında değerlendirilmesi. Demiryolu Mühendisliği, 10, 31-45.

Railwayrail. 2015. https://www.railwayrail.com/ download/profile-section-of-49e1-s49-steel-rail/ 12 Ocak 2020.

Seyitoğlu, G., Kaypak, B., Aktuğ, B., Gürbüz, E., Esat, K., Gürbüz, A., 2016. A hypothesis for the alternative southern branch of the North Anatolian Fault Zone, Northwest Turkey. Türkiye Jeoloji Bülteni, 59 (2), 115-130.

Sönmez, H., 2004. HS Jeotek, Jeoteknik Paket Programı, Hacettepe Üniversitesi, Mühendislik Fakültesi Vakfi.

Stenström, C., Parida, A., Galar. D., 2012. Performance indicators of railway infrastructure. International Journal of Railway Technology, 1 (3), 1-18.

Şafak, Ü., Kaya, M., 2016. Köprüköy / Erzurum (Doğu Anadolu) yöresi Ostrakod Faunası ve ortamsal özellikleri. Maden Tetkik ve Arama Dergisi, 153, 113-137.

Şenlik, İ., 2013. Kent içi raylı ulaşım sistemlerinin değerlendirilmesi. Elektrik Mühendisleri Odası. 24-26.

Tarhan, R., 2009. Raylı sistemlerde ölçme teknikleri ve donanımları. Harita ve Kadastro Mühendisleri Odas1, 12. Türkiye Harita Bilimsel ve Teknik Kurultay1, 11-15 Mayıs 2009, Ankara. Akpınar, B., 2005. Şehir içi raylı sistemlerde deformasyon ölçmeleri. Harita ve Kadastro Mühendisleri 
Odası, Mühendislik Ölçmeleri STB Komisyonu 2. Mühendislik Ölçmeleri Sempozyumu, 23-25 Kasım 2005, İstanbul, 18-27.

TBDY. (2018). Türkiye Bina Deprem Yönetmeliği. Ankara: Afet ve Acil Durum Yönetimi Başkanlı̆̆1.

Tekin, B.M., Sagular E.K., 2016. Jeolojik çözümlemelerde uydu görüntüleri destekli coğrafi bilgi sistemi (CBS) yöntemleri; yeni Foça (İzmir) yöresi örneği. Türkiye Jeoloji Bülteni, 59 (1), 37-54.
Yıldırım, N., Parlak, O., 2008. Tekman-Pasinler (Erzurum) arasında yüzeyleyen ofiyolitik birimlerin jeolojisi ve petrografik özellikleri. Çukurova Üniversitesi Fen Bilimleri Enstitüsü Dergisi, 18 (2), 35-45.

Yılmaz, A., Terlemez, İ., Uysal, Ş., 1988. Hınıs (Erzurum güneydoğusu) dolaylarının bazı stratigrafik ve tektonik özellikleri. MTA Dergisi, $108,38-56$.

Y1lmaz, H., Y1lmaz, A., 2016. Oltu-Balkaya havzasının (KD Türkiye) tektonik konumu ve Geç Kretase sonrası jeolojik evrimi. Türkiye Jeoloji Bülteni, 59 (1), 1-25. 